\title{
Zemin Büyütme Katsayılarının Betonarme Taşıyıcı Sistemlerin Sismik Performans Potansiyeline ve Maliyetine Etkileri
}

\author{
Peyman AZíMí

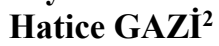 \\ Cenk ALHAN ${ }^{3}$
}

ÖZ

$\mathrm{Bu}$ çalışmada, zemin koşullarına bağlı olarak değişen zemin büyütme katsayıları ile oluşturulan farklı yönetmeliklerdeki farklı tasarım ivme spektrumlarının kullanılmasının bina türü yapıların betonarme taşıyıcı sistemlerinin maliyetine ve sismik performans potansiyeline olan etkileri karşılaştırmalı olarak araştırılmıştır. Bu amaçla, farklı kat sayılarına sahip prototip betonarme binalar, farklı zemin sınıfları için oluşturulan Deprem Bölgelerinde Yapılacak Binalar Hakkında Yönetmelik (DBYBHY2007), Uniform Building Code (UBC97) ve Minimum Design Loads for Buildings and Other Structures (ASCE/SEI 7-10) yönetmeliklerindeki tasarım ivme spektrumları kullanılarak tasarlanmış ve betonarme taşıyıcı sistemlerin maliyet karşılaştırmaları yapılmıştır. Ayrıca, tasarımı yapılan taşıyıcı sistemlerin zaman tanım alanı analizleri temsili tarihi deprem kayıtları altında gerçekleştirilerek sismik performans potansiyelleri karşılaştırılmıştır.

Anahtar Kelimeler: Zemin büyütme katsayıları, spektral analiz, zaman tanım analizi, sismik performans potansiyeli, yapı maliyeti.

\section{ABSTRACT \\ Effects of Soil Amplification Factors on the Seismic Performance Potential and Cost of Reinforced Concrete Structural Systems}

In this study, the effect of using different design acceleration spectra of different seismic codes, which are constructed using soil amplification factors which vary depending on the soil conditions, on the cost and seismic performance potential of reinforced concrete structural systems of buildings is investigated comparatively. Accordingly, prototype

\footnotetext{
Not: Bu yaz1

- Yayın Kurulu’na 8 Mart 2017 günü ulaşmıştır. 17 Nisan 2018 günü yayımlanmak üzere kabul edilmiştir.

- 31 Mart 2019 gününe kadar tartışmaya açıktır.

- DOI: $10.18400 /$ tekderg.308431

1 İstanbul Üniversitesi - Cerrahpaşa, İnşaat Mühendisliği Bölümü, İstanbul - peyman.azimi90@gmail.com

2 İstanbul Üniversitesi - Cerrahpaşa, İnşaat Mühendisliği Bölümü, İstanbul - hgazi@istanbul.edu.tr

3 İstanbul Üniversitesi - Cerrahpaşa, İnşaat Mühendisliği Bölümü, İstanbul - cenkalhan@istanbul.edu.tr
} 
reinforced concrete buildings of different number of stories are designed using design acceleration spectra defined in the Turkish Earthquake Code (DBYBHY2007), Uniform Building Code (UBC97) and Minimum Design Loads for Buildings and Other Structures (ASCE/SEI 7-10) that are generated for different soil types and cost comparisons of the reinforced concrete structural systems are carried out. In addition, time history analyses of these structural systems are carried out for representative historical earthquake records and their seismic performances are compared.

Keywords: Soil amplification factors, response spectrum analysis, time history analysis, seismic performance potential, structural cost.

\section{GİRIŞ}

Deprem sırasında, ana kayadaki deprem dalgalarının özellikle yumuşak zeminlerde ortaya çıkan zemin büyütmesine uğraması, hem frekans içeriğinin değişmesine hem de genliklerin büyümesine neden olabilmektedir. Bu durum, üst yapıda tasarım yüklerinin artmasına yol açabilmektedir. DBYBHY2007 [1]'de, deprem yüklerini belirleyen tasarım ivme spektrumu, zemin sınıfına göre $T_{A}$ ve $T_{B}$ adı verilen spektrum karakteristik periyotlarının değiştirilmesi suretiyle değiştirilmektedir. Böylece daha kötü zemin sınıfları için kullanılan daha yüksek $T_{B}$ değerleri vasitasıyla zemin büyütmesinin etkisi, esasen görece uzun periyotlu ve esnek yapılar için olmak üzere dolaylı olarak göz önüne alınmaktadır. Bu yönetmelikte doğrudan tanımlanan zemin büyütme katsayıları bulunmamaktadır. Öte yandan, UBC97 [2] ve ASCE/SEI 7-10 [3] gibi Amerikan yönetmeliklerinde ve 1 Ocak 2019 tarihinde yürürlüğe girecek olan Türk Bina Deprem Yönetmeliği'nde ise; zemin koşullarına bağlı olarak, spektrum karakteristik periyotlarının değiştirilmesine ek olarak yönetmelikte açıkça tanımlanan zemin büyütme katsayıları vasıtasıyla da daha kötü zemin koşulları için tasarım ivme spektrumu hem kısa hem de uzun periyotlu yapıları etkileyecek şekilde doğrudan büyütülmektedir. Bu durum, daha kötü zemin koşulları için, yapıların taşıyıcı sistemlerinin daha büyük deprem kuvvetlerine göre tasarlanması anlamına gelmektedir. Buna bağlı olarak, farklı zemin bölgelerinde tasarlanan betonarme taşıyıcı sistemlerin eleman boyutları da farklı olabilmektedir. $\mathrm{Bu}$ ise, maliyeti ve sismik performans potansiyelini etkilemekte olup bu etkinin değerlendirilmesi, farklı yönetmeliklerde farklı şekilde dikkate alınan zemin büyütme katsayılarının kullanılmasının gerekliliği ve yeterliliği hakkında bir değerlendirme yapılabilmesi açısından önemlidir.

Deprem mühendisliği ve sismik tasarım açısından, uyarma ile tepki arasındaki ilişkiyi en açık biçimde ifade eden araç deprem spektrumudur. Deprem spektrumları, tasarım açısından oldukça önemli bir işleve sahip olan maksimum tepkiyi doğrudan ifade eder. Spektral değerler, odak, odak çevresi ve fay ara yüzleri boyunca enerjinin açığa çıkma mekanizması, odak derinliği, jeolojik değişimler ve depremin büyüklüğü gibi etmenlerin yanı sıra kayıt istasyonunun bulunduğu bölgedeki yerel zemin koşullarını da içeren birçok faktöre bağlıdır [4]. Yerel zemin koşulları büyük depremlerden gelen sismik dalgaların hasar olasılığının belirlenmesinde önemli bir rol oynamaktadır [5]. Araştırma çalışmalarından elde edilen sonuçlar doğrultusunda ve Loma Prieta (1989), Northridge (1994), Kobe (1995) gibi meydana gelen birçok büyük deprem sonucunda, deprem yönetmelikleri genellikle yerel zemin koşullarının önemli rol oynadığını kabul etmiştir [6]. 
Zemin büyütmesi, geçmişte meydana gelen birçok yıkıcı depremde ortaya çıkmıştır. Gediz depremi (1970), Romanya depremi (1979), Mexico City depremi (1985) ve Loma Prieta depremi (1989), zemin büyütme etkisinin görüldüğü depremlerden başlıcalarıdır [7]. 1985 Michoacan depreminden sonra Mexico City'de görülen hasarlar, yerel zemin koşullarının sismik yanıt üzerindeki etkileri hakkında incelemelerin başlamasına sebep olmuştur. Ana kayadan yeryüzüne çıkan dalgaların genlikleri şehrin göl yatağına kurulmuş bölgesinde yaklaşık beş kat büyümüştür. Kil zeminin yakınında bulunan yapılar üzerinde büyütülmüş dalgaların yıkıcı etkileri olmuştur. Benzer şekilde 1989'da meydana gelen Loma Prieta depreminde de aynı sonuçlara yakın bir durum ortaya çıkmıştır. Netice itibariyle, sismik tasarımda, yerel zemin koşullarının büyütme etkilerinin önemi açıkça ortadadır [5].

Zemin büyütme etkileri ve bu etkilere maruz kalan yapıların davranışları üzerine literatürde birçok araştırma mevcuttur. Örneğin, Trifunac [8], frekansa bağlı zemin büyütme faktörlerinin fiziksel tarifini, bölgesel zemin ve jeolojik çevre koşullarına bağlı olarak ortaya koyan basit bir denklem önermiştir. Bouckovalas ve Kouretzis [9], 1999 Atina depreminde sert zeminlerde ortaya çıkan amplifikasyonun etkilerini incelemiştir. Böylece NEHRP-97 [10] ve EC-8 [11] yönetmeliklerinde yer alan sıkı zeminlerin ve yumuşak kayaların aynı zemin sınıfında yer almasının olumsuz etkileri ve söz konusu şartnamelerin eksikliğini ortaya konmuştur. Şafak [12], zemin büyütme türleri ve bu fenomeni üreten mekanizmaları gözden geçirerek deprem kayıtlarını karakterize etmek amacıyla kullanılan modeller ve yöntemler hakkında bilgi sunmuştur. Finn ve Wightman [5], deprem yönetmeliklerinde zemin koşullarının sınıflandırılması ve çeşitli zemin sınıflarına yoğunluk ve frekansa bağlı büyütme faktörlerinin atanması hakkında dönemin gelişmelerini ortaya koymuş ve Kanada Ulusal Yapı Kanunu 2005 (NBCC 2005) sürümünde önerilen yeni zemin büyütme faktörlerini değerlenmiştir. Zaslavsky ve diğ. [13], yerel zemin sınıflandırmasına göre ivme tepki spektrumlarını doğrulamak amacıyla $V_{s, 30}$ parametresi ve ilgili $F_{a}$ ve $F_{v}$ faktörlerine bağlı olan NEHRP-97 [10] zemin sınıflandırmasının uygulanabilirliğini, İsrail bina standartları için incelemiştir. Zemin sınıflandırması ve dolayısıyla zemin amplifikasyonu genelleştirmesinin, tek bir parametre, yani $V_{s, 30}$ vasıtasıyla tavsiye edilemeyeceği sonucuna varmışlardır. Ayrıca, İsrail jeolojisinin kısa mesafelerde ciddi biçimde değişebilmesi nedeniyle aynı sınıftaki zeminlerde, hem şekil hem de genlik ve frekans açısından farklılıklar görüldüğü ortaya konmuştur. Şişman [14], zeminlerin dinamik özelliklerinin ve zemin büyütme faktörlerinin belirlenmesi amacıyla alternatif iki yöntem kullanarak elde edilen büyütme faktörlerini birbirleriyle karşılaştırmıştır. Sonuç olarak hakim frekans ve zemin büyütme faktörü açısından birbiri ile uyumlu sonuçlar elde edilmiştir. Zemin büyütme etkilerinin önemini ortaya koyan ve bu etkilerin yapısal tasarımda dikkate alınması gerektiğine doğrudan veya dolaylı olarak işaret eden bu çalışmaların yanı sıra [7], [15], [16], [17], [18], [19], [20], [21] ve [22] de zemin büyütme faktörleri ile ilgili diğer araştırma çalışmaları arasında sayılabilir.

$\mathrm{Bu}$ çalışmada ise, zemin büyütmesi etkisini dikkate almak amacıyla yönetmeliklerde tanımlanmış olan zemin büyütme katsayılarının betonarme taşıyıcı sistemlerin sismik performans potansiyeline ve maliyetine etkilerinin incelenmesi amaçlanmış olup; bu amaç doğrultusunda farklı kat sayılarına $(2,5,10$ ve 15) sahip prototip betonarme binalar farklı zemin sınıfları için oluşturulan DBYBHY2007 [1], UBC97 [2] ve ASCE/SEI 7-10 [3] tasarım ivme spektrumları kullanılarak tasarlanmış ve tasarlanan bu binaların betonarme taşıyıcı sistemlerinin maliyetleri ile dört adet tarihi deprem kaydı altındaki performans potansiyelleri karşılaştırılmıştır. DBYBHY2007'ye göre 1. derece deprem bölgesinde bulunduğu varsayılan söz konusu binaların sismik performans potansiyeli 
karşılaştırmalarında en üst kat deplasmanları ve göreli kat öteleme oranları göz önünde bulundurulmuştur. 1 Ocak 2019 tarihinde yürürlüğe girecek olan yeni deprem yönetmeliğimizde (Türk Bina Deprem Yönetmeliği - TBDY2019) eski deprem tasarım spektrumu formülasyonunun terk edilerek zemin büyütme katsayılarının kullanıldığ ASCE/SEI 7-10'a çok yakın bir deprem tasarım spektrumunun tanımlanıyor olması dikkate alındığında, bu çalışmada yer alan ASCE/SEI 7-10 sonuçları ile DBYBHY2007 sonuçlarının karşılaştırılması, bir anlamda TBDY 2019'un bu açıdan değerlendirilmesine de yardımcı olacaktır. TBDY 2019'da söz konusu zemin büyütme katsayılarının kullanılması, deprem mühendisliği camiasında ilk bakışta taşıyıcı sistemlerin DBYBHY2007'ye kıyasla daha yüksek spektal ivmelere göre tasarlanacağı ve daha maliyetli olacağı intibaını uyandırabilir. $\mathrm{Bu}$ çalışma, söz konusu algının gerçeği yansıtıp yansıtmadığının ortaya konması açısından da önem arz etmektedir.

Bu çalışmanın 2. Bölümünde DBYBHY2007 [1], UBC97 [2] ve ASCE/SEI 7-10 [3] tasarım ivme spektrumları hakkında bilgi verilmiş ve söz konusu spektrumlar özellikle ilgili yönetmelikte tanımlanan zemin büyütme katsayıları açısından karşılaştırılmıştır. Çalışma kapsamında uygulanan yöntem, 3. Bölüm'de verilmiş olup; 4. Bölümde incelenen binalar için geçekleştirilen spektral analizlerin ve daha sonrasında da seçilen dört yer hareketi etkisinde gerçekleştirilen zaman tanım analizlerinin bulgularına yer verilmiştir. 5. Bölümde ise, çalışma kapsamında elde edilen tüm bulgular doğrultusunda elde edilen sonuçlar bulunmaktadir.

\section{TASARIM SPEKTRUMLARI}

Tasarım spektrum grafiği, deprem etkisine maruz kalan yapının tasarıma esas deprem kuvvetlerini belirleyen eğri olup yönetmeliklerde genellikle tasarım ivme spektrumu kullanılmaktadır. Bu çalışma kapsamında DBYBHY2007, UBC97 ve ASCE/SEI 7-10 yönetmeliklerinde yer alan tasarım ivme spektrumları ele alınmış olup spektrumlar hakkında detaylı bilgi, sırasıyla Bölüm 2.1, 2.2 ve 2.3'de verilmiştir.

\subsection{DBYBHY2007 Tasarım İvme Spektrumu}

DBYBHY2007'de yer alan elastik tasarım ivme spektrumu, yerel depremsellik ve zemin koşulları göz önüne alınarak belirlenmektedir. Bu nedenle, öncelikle ilgili parametrelerin tarif edilmesinde fayda vardır. Bu parametrelerden biri olan Etkin Yer İvme Katsayısı $\left(A_{0}\right)$, DBYBHY2007 Tablo 2.2'den görülebileceği üzere, deprem bölgelerine göre değişkenlik göstermektedir ve 1., 2., 3. ve 4. deprem bölgelerinde sırasıyla $0.4,0.3,0.2$ ve 0.1 değerlerini almaktadır. Bir diğer parametre ise, bina kullanım amacına veya türüne bağlı olarak Bina Önem Katsayısı (I) olarak adlandırılmış olup bu parametrenin aldığ değerler, DBYBHY2007 Tablo 2.3'de tanımlandığ 1 üzere önemli binalardan daha az önemli olan binalara doğru azalacak şekilde $1.5 \sim 1.0$ arasında değişen değerler almaktadır.

DBYBHY2007'de zemin sınıflarını tanımlamak için ise öncelikle zemin grupları belirlenmektedir. Zemin grupları, DBYBHY2007 Tablo 6.1'de verilmiş olup en iyi zeminden en kötü zemine doğru olacak şekilde A, B, C ve D olarak isimlendirilen 4 zemin grubu bulunmaktadır. $\mathrm{Bu}$ zemin grupları göz önüne alınarak tanımlanan zemin sınıfları ise, DBYBHY2007 Tablo 6.2'de sunulmuştur. İlgili tabloya göre, yine en iyiden en kötüye doğru 
olacak şekilde Z1, Z2, Z3 ve Z4 olarak isimlendirilen 4 zemin sınıfı bulunmakta olup söz konusu zemin sinıfları, zemin gruplarının yanı sira, bu grupların zemin tabakası yüksekliklerine bağlı olarak belirlenmektedir. DBYBHY2007 Tablo 2.4'de $T_{A}$ ve $T_{B}$ olarak isimlendirilen zemin karakteristik periyotları tanımlanmıştır ve zemin sınıflarına bağlı olarak değişmektedir. Bu doğrultuda, $\left(T_{A}-T_{B}\right)$ değerleri ile belirlenen tasarım ivme spektrumunun sabit ivme bölgesini belirleyen aralık, Z1, Z2, Z3 ve Z4 zemin sınıfları için giderek artmakta olup bu aralıklar sirasiyla $(0.10-0.30),(0.15-0.40),(0.15-0.60)$ ve $(0.20-0.90)$ saniyedir.

Spektrum katsayısı $S(T)$ ise, $T_{A}$ ve $T_{B}$ spektrum karakteristik periyotları kullanılarak; Şekil 1'deki gibi elde edilmektedir. Bu şekilden de görüleceği üzere, $T_{A}$ ve $T_{B}$ periyotları, spektrum katsayısı grafiğinde yer alan sabit ivme bölgesinin alt ve üst sınırlarını göstermektedir. Diğer taraftan yukarıdaki gibi tanımlanan $S(T), A_{0}$ ve $I$ parametreleri ile yer çekimi kuvveti $(g)$ çarpılarak elastik ivme spektrumunun ordinatı olan elastik spektral ivme $S_{a}(T)$ parametresi aşağıdaki gibi elde edilmektedir:

$$
S_{a}(T)=S(T) \times\left(A_{0} \times I \times g\right)
$$

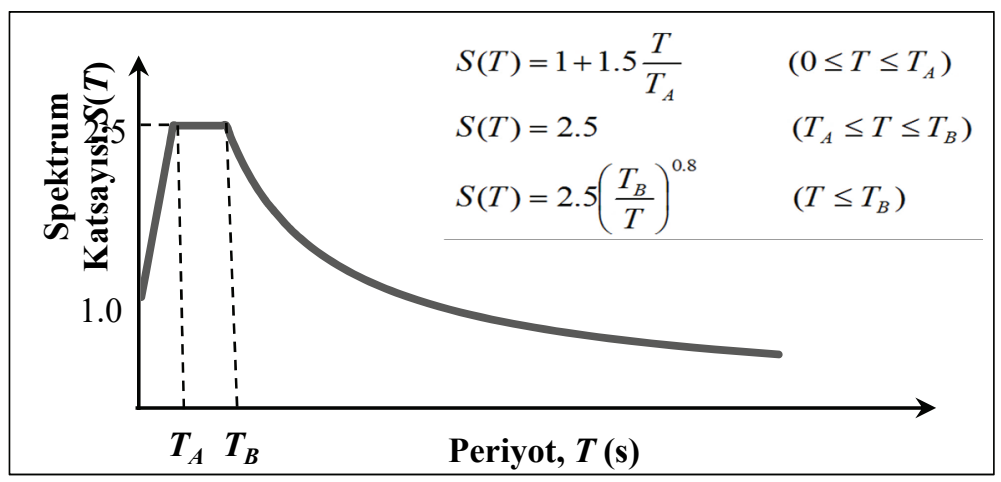

Şekil 1 - DBYBHY2007'de Yer Alan Tasarım İvme Spektrum Katsayısı

Konut türü bina $(I=1)$ ve 1 . derece deprem bölgesi $\left(A_{0}=0.4\right)$ için; farklı zemin sınıflarına göre oluşturulan tasarım ivme spektrumları, Şekil 2'deki gibi elde edilebilir. Bu şekilde görüldüğü gibi farklı zemin sınıfları için sırasıyla en iyi zeminden (Z1) en kötü zemine (Z4) doğru tasarım ivme spektrumlarının azalan uzun-periyot bölümlerinde (sabit hız bölgesi) spektral değerler artarken; sabit ivme bölgesinde ise spektral değerler aynı $(1.0 \mathrm{~g})$ kalmakta ancak söz konusu kısım Z1'den Z4'e doğru genişlemektedir. Aynı bir doğal periyot değeri için en büyük farklılıkların uzun-periyot bölgesinde gerçekleştiği görülmektedir. Bu durum daha detaylı olarak Bölüm 2.5'te incelenecektir. 


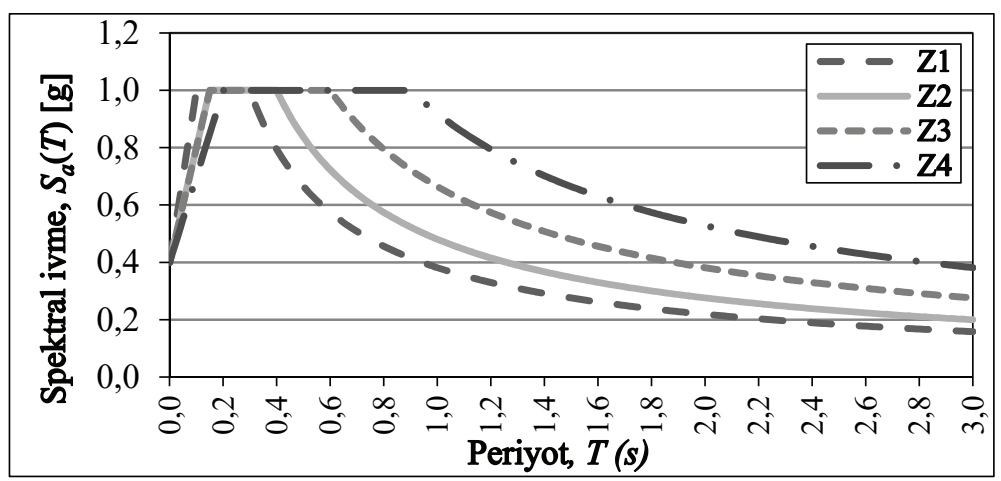

Şekil 2 - DBYBHY2007'de Farklı Zemin Sinıflarına Göre Tasarım İvme Spektrumları $\left(A_{0}=0.4\right.$ ve $I=1$ için $)$

\subsection{UBC97 Tasarım İvme Spektrumu}

UBC97'de, DBYBHY2007'deki gibi ayrıca bir spektrum katsayısı tanımlanmamakta; doğrudan $g$ cinsinden tasarım ivme spektrumu kullanılmaktadır. Tasarım ivme spektrumu, zemin koşulları, deprem bölgesi ve fay hattına olan mesafeye bağlı olarak değişmektedir.

Anılan şartnamede ortaya konan tasarım ivme spektrumunun oluşturulmasında en önemli parametreler, sismik katsayılar olarak tanımlanan $C_{a}$ ve $C_{v}$ olup; tasarım ivme spektrumu, söz konusu $C_{a}$ ve $C_{v}$ sismik katsayıları ve yapının periyoduna $(T)$ bağlı olarak, Şekil 3'teki gibi elde edilir. $\mathrm{Bu}$ şekilde görüldüğü üzere, tasarım ivme spektrumunun sabit-ivme bölümünün alt ve üst sınırlarını gösteren ve yerel zemin koşullarına göre değişen karakteristik periyotlar $T_{0}$ ve $T_{S}$ olarak adlandırılmış olup; $C_{a}$ ve $C_{v}$ katsayılarına bağlı olarak, yine aynı şekil üzerinde verilen denklemler ile elde edilmektedir.

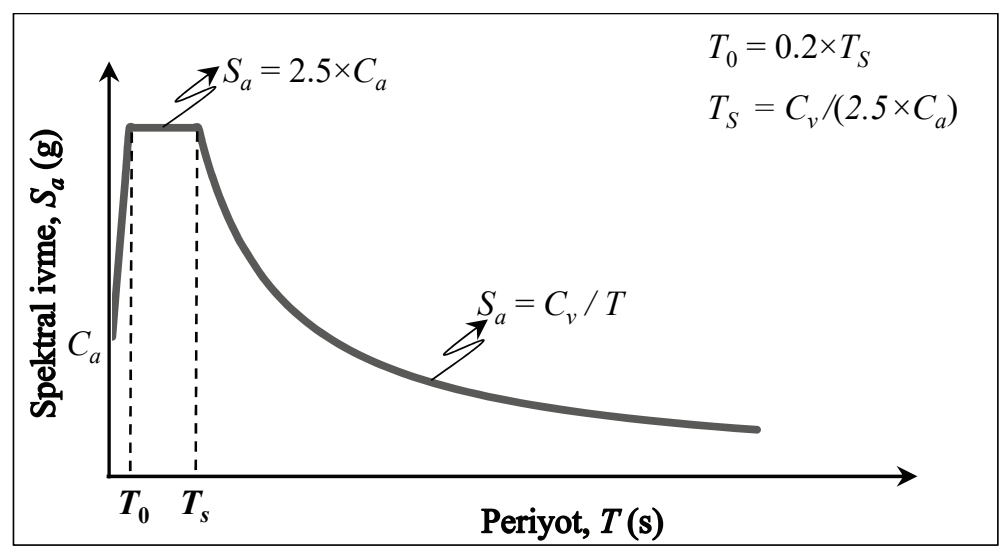

Şekil 3 - UBC97 Yönetmeliği Tasarım İvme Spektrumu 
$C_{a}$ ve $C_{v}$ sismik katsayıları ise zemin sınıfı, sismik bölge faktörü $(Z)$ ve $N_{a}, N_{v}$ yakın kaynak katsayılarına bağlı olarak değişmektedir. Bu parametrelerden $Z$ sismik bölge faktörü, DBYBHY2007'deki etkin yer ivmesi katsayssina $\left(A_{0}\right)$ denk gelmekte olup; UBC97'de tanımlanmış olan deprem bölgelerine bağlı olarak değerler almaktadır. UBC97'de deprem bölgeleri beş farklı bölgeye (1, 2A, 2B, 3 ve 4) ayrılmaktadır. $Z$ faktörü ise, Deprem bölgesi 1'den Deprem bölgesi 4'e doğru $0.075 \sim 0.4$ aralığında artarak değişen değerler almaktadır (UBC97 Tablo 16-I). $N_{a}$ ve $N_{v}$ yakın kaynak katsayıları ise; sırasıyla UBC97 Tablo 16-S ve Tablo 16-T'de verilmekte olup sismik kaynak türü ile faya olan en yakın mesafeye göre değişen değerler almakta ve yakın mesafe deprem etkilerini spektral ivme değerlerine yansıtmak için kullanılmaktadır. $N_{a}$ ve $N_{v}$ katsayılarının tanımlanmasında kullanılan sismik kaynak türü, UBC97'de Maksimum Moment Magnitüdü $(M)$ ve Kayma Hızı (SR)'na bağlı olarak üçe ayrılmaktadır: A türü sismik kaynak, sismik aktivitesi yüksek olan (kayma hızı en az $5 \mathrm{~mm} / \mathrm{sene})$ ve büyük magnitüdlü $(M \geq 7)$ depremleri yaratma gücüne sahip sismik kaynaktır. B türü sismik kaynak, A ve C sismik kaynak türü olmayan sismik kaynaktır. C türü sismik kaynak ise, sismik aktivitesi nispeten düşük (en fazla $2 \mathrm{~mm} / \mathrm{sene}$ ) olan ve büyük magnitüdlü depremleri yaratma potansiyeli olmayan $(M<6.5)$ sismik kaynaktır.

UBC97'de, yukarıda kısaca özetlenmiş olan $Z, N_{a}$ ve $N_{v}$ parametrelerine bağlı olarak tanımlanan $C_{a}$ ve $C_{v}$ katsayılarının aldığı değerler, sırasıyla ilgili yönetmelikte yer alan 16-Q ve 16-R tablolarında sunulmuş olup bu katsayılar iyi zeminden kötü zemine doğru artmaktadırlar. Yani zemin büyütmesi etkileri bu katsayıların içerisinde gizli bir çarpan olarak yer almaktadır ve zemin büyütme etkisini tarif etmek üzere ayrıca bir zemin büyütme katsayısı tanımlanmamıştır. Durum, ilgili tablolardaki değerler kullanılarak bir örnekle açıklanacak olursa, Deprem Bölgesi 1'de $(Z=0.075)$ SA zemin sınıfı için $C_{a}$ katsayısı 0.06 iken, yine aynı deprem bölgesinde SA'ya göre daha kötü bir zemin sınıfı olan SD zemin sınıfı için $C_{a}$ katsayısı değeri 2 katına çıkmakta ve 0.12 'ye eşit olmaktadır. Benzer şekilde, Deprem Bölgesi 2B'de $(Z=0.2)$ SB zemin sınıfı için $C_{v}$ katsayısı 0.20 iken, yine aynı deprem bölgesinde SB'ye göre daha kötü olan SE zemin sınıfı için $C_{v}$ katsayısı değeri 3.2 katına çıkmakta ve 0.64 'e eşit olmaktadır. Sismik açıdan en aktif bölge olan Deprem bölgesi 4 (DBYBHY2007'de 1. derece deprem bölgesine denk gelmektedir) için $(Z=0.4)$ ise, $C_{a}$ ve $C_{v}$ katsayılarının hesabında sırasıyla $N_{a}$ ve $N_{v}$ de ayrıca birer yakın-kaynak büyütme çarpanı olarak yer almaktadır.

UBC97'de zemin profilleri, zeminlerin kayma dalgası hızı $\left(V_{s}\right)$, standart penetrasyon sayıs1 $\left(N_{S P T}\right)$, drenajsız kayma mukavemeti $\left(S_{u}\right)$ ve plastisite indeksi $(P I)$ parametrelerine bağlı olarak en iyiden en kötüye doğru SA, SB, SC, SD, SE ve SF olarak isimlendirilmiş olan altı farklı sınıfta tanımlanmaktadır. Söz konusu zemin sınıflarına ait detaylı bilgiler, UBC97 Tablo 16-J'te verilmiştir. Sismik açıdan en aktif bölge olan Deprem bölgesi $4(Z=0.4)$ ve yakın kaynak etkilerine bağlı olarak ayrıca bir büyütme etkisi olmayan durumlar $\left(N_{a}=N_{v}=\right.$ 1) için, SA, SB, SC, SD, SE ve SF zemin sınıflarına ait UBC97 tasarım ivme spektrumlarının değişimi, Şekil 4'te verilmiştir. Bu şekilden de görüleceği üzere; spektral ivme değerleri referans zemin sınıfı olan SB'ye göre (DBYBHY2007'de Z2 zemin sinıfina denk gelmektedir) daha kötü olan zeminler için (SC, SD ve SE) artmakta, daha iyi olan zemin (SA) için ise azalmaktadır. Burada dikkati çeken husus, zemin kötüleştikçe sabit-ivme bölgesi genişlemekle birlikte DBYBHY2007'dekinden farklı olmak üzere bu bölgede ayrıca artış da göstermektedir. 


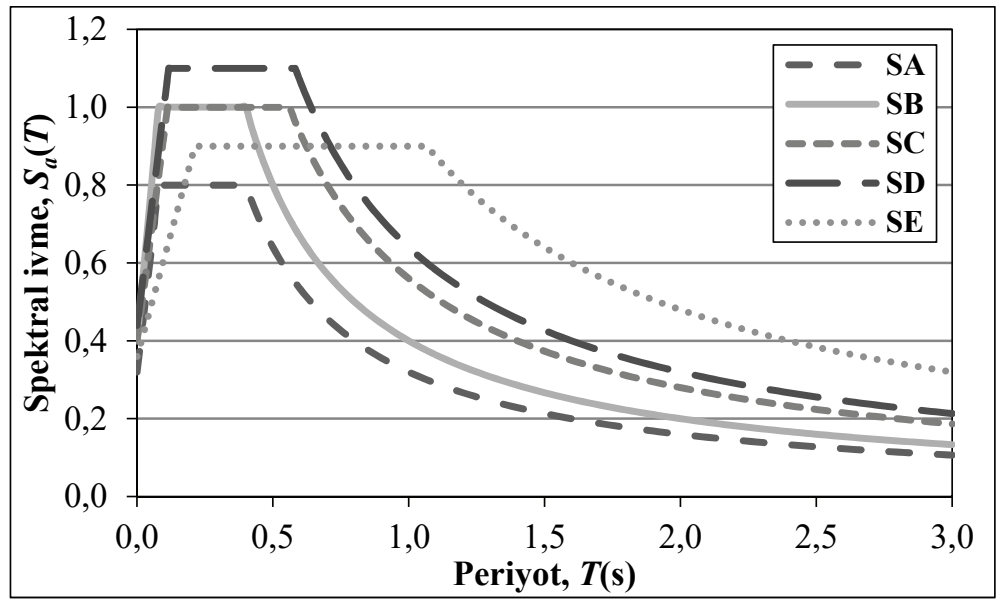

Şekil 4 - UBC97 Tasarım Ivme Spektrumları $\left(Z=0.4\right.$, faya olan mesafe $\left.\geq 15 \mathrm{~km}: N_{a}=N_{v}=1\right)$

\subsection{ASCE/SEI 7-10 Tasarım İvme Spektrumu}

ASCE/SEI 7-10 tasarım ivme spektrumlarının oluşturulması için izlenecek yöntem, adım adım şöyledir:

1) ASCE/SEI 7-10 Tablo 20.3-1'e göre zemin sınıfı belirlenir. Bu yönetmeliğe göre zeminler, zeminin kayma dalgası hızı $\left(V_{s}\right)$ esas alınarak en iyi zeminden en kötü zemine doğru A, B, $\mathrm{C}, \mathrm{D}, \mathrm{E}$ ve $\mathrm{F}$ olarak isimlendirilen altı sınıfa ayrılmaktadır. $V_{s}$ 'in bilinmediği yerlerde, zemin sınıfını belirlemek için bölgenin ortalama standart penetrasyon direnci $(\bar{N})$ ve drenajsız kayma mukavemeti $\left(S_{u}\right)$ değerleri kullanılmaktadır.

2) Tasarım ivme spektrumunun oluşturulabilmesi için gerekli diğer parametreler, harita spektral ivme katsayıları olarak isimlendirilen $S_{S}$ ve $S_{1}$ katsayılarıdır. \%5 sönüm oranı için dikkate alınmış maksimum spektral ivme, 0.2 ve 1.0 saniye olan yapısal periyotlar için sırasıyla $S_{S}$ ve $S_{1}$ olarak adlandırılmış olup bu katsayılar, Amerika Birleşik Devletleri sınırları dâhilinde yer alan herhangi bir coğrafik konum için bu şartnamede bulunan haritalarda (ASCE/SEI 7-10'da verilen Şekil (22-1) (22-6)) gösterilmektedir. Bu haritalar, $S_{S}$ ve $S_{1}$ 'in sabit değerlerinin konturlarını göstermekte olup; her kontur hattı g'nin yüzdesi olarak etiketlenmiştir.

3) Tablo 1 kullanılarak zemin katsayıları $\left(F_{a}\right.$ ve $\left.F_{v}\right)$ değerleri, belirlenir. Bu tabloda, $S_{S}$ ve $S_{1}$ 'in iki sütun arasında olan herhangi bir değeri için $F_{a}$ ve $F_{v}$ değerleri enterpolasyon yöntemi kullanılarak elde edilmektedir.

4) Daha önce belirlenmiş olan harita spektral ivme katsayıları $S_{S}$ ve $S_{1}$, farklı zemin sınıfları için zemin büyütme etkilerini yansıtabilmek amacıyla kısa ve uzun periyotlarda sırasıyla zemin katsayıları $F_{a}$ ve $F_{v}$ ile çarpılarak, maksimum deprem seviyesinde $\% 5$ sönüm için sirasıyla $S_{M S}$ ve $S_{M 1}$ olarak tanımlanan spektral ivme parametreleri elde edilir:

$$
\begin{aligned}
& S_{M S}=F_{a} \times S_{S} \\
& S_{M I}=F_{v} \times S_{1}
\end{aligned}
$$


Tablo 1 - ASCE/SEI 7-10'a Göre Zemin Katsaylları $F_{a}$ ve $F_{v}$.

\begin{tabular}{|c|c|c|c|c|c|c|c|c|c|c|}
\hline \multirow{2}{*}{$\begin{array}{c}\text { Zemin } \\
\text { sinıfi }\end{array}$} & $\boldsymbol{F}_{\boldsymbol{a}}$ & $\boldsymbol{F}_{\boldsymbol{v}}$ & $\boldsymbol{F}_{\boldsymbol{a}}$ & $\boldsymbol{F}_{\boldsymbol{v}}$ & $\boldsymbol{F}_{\boldsymbol{a}}$ & $\boldsymbol{F}_{\boldsymbol{v}}$ & $\boldsymbol{F}_{\boldsymbol{a}}$ & $\boldsymbol{F}_{\boldsymbol{v}}$ & $\boldsymbol{F}_{\boldsymbol{a}}$ & $\boldsymbol{F}_{\boldsymbol{v}}$ \\
\cline { 2 - 12 } & $\boldsymbol{S}_{\boldsymbol{s}} \leq \mathbf{0 . 2 5}$ & $\boldsymbol{S}_{\mathbf{1}} \leq \mathbf{0 . 1}$ & $\boldsymbol{S}_{\boldsymbol{s}}=\mathbf{0 . 5}$ & $\boldsymbol{S}_{\mathbf{1}}=\mathbf{0 . 2}$ & $\boldsymbol{S}_{\mathbf{s}}=\mathbf{0 . 7 5}$ & $\boldsymbol{S}_{\mathbf{1}}=\mathbf{0 . 3}$ & $\boldsymbol{S}_{\mathbf{s}}=\mathbf{1 . 0}$ & $\boldsymbol{S}_{\mathbf{1}}=\mathbf{0 . 4}$ & $\boldsymbol{S}_{\boldsymbol{s}} \geq \mathbf{1 . 2 5}$ & $\boldsymbol{S}_{\mathbf{1}} \geq \mathbf{0 . 5}$ \\
\hline $\mathbf{A}$ & 0.8 & 0.8 & 0.8 & 0.8 & 0.8 & 0.8 & 0.8 & 0.8 & 0.8 & 0.8 \\
\hline $\mathbf{B}$ & 1.0 & 1.0 & 1.0 & 1.0 & 1.0 & 1.0 & 1.0 & 1.0 & 1.0 & 1.0 \\
\hline $\mathbf{C}$ & 1.2 & 1.7 & 1.2 & 1.6 & 1.1 & 1.5 & 1.0 & 1.4 & 1.0 & 1.3 \\
\hline $\mathbf{D}$ & 1.6 & 2.4 & 1.4 & 2.0 & 1.2 & 1.8 & 1.1 & 1.6 & 1.0 & 1.5 \\
\hline $\mathbf{E}$ & 2.5 & 3.5 & 1.7 & 3.2 & 1.2 & 2.8 & 0.9 & 2.4 & 0.9 & 2.4 \\
\hline F & \multicolumn{8}{|c|}{ Bölge tepki analizi (site response analiz) ASCE/SEI 7-10 Bölüm 21.1'e göre yapılacaktır. } \\
\hline
\end{tabular}

5) Bir önceki adımda hesaplanan spektral ivme parametreleri $\left(S_{M S}\right.$ ve $\left.S_{M 1}\right)$ kullanılarak, yine $\% 5$ sönüm için tasarım depremi seviyesinde sırasıyla kısa ve uzun periyot tasarım spektral ivme parametreleri olarak tanımlanan $S_{D S}$ ve $S_{D 1}$ parametreleri aşağıdaki gibi hesaplanır:

$S_{D S}=\frac{2}{3} \times S_{M S}$

$S_{D 1}=\frac{2}{3} \times S_{M 1}$

6) Tasarım ivme spektrumunun karakteristik periyotları ( $T_{0}$ ve $T_{\mathrm{S}}$ ), bir önceki adımda belirlenen tasarım spektral ivme parametreleri $\left(S_{D S}\right.$ ve $\left.S_{D 1}\right)$ kullanılarak, SSekil 5'de verilen formüllerle hesaplanır. $T_{0}$ ve $T_{\mathrm{S}}$ karakteristik periyotları, spektrumun sabit-ivme bölümünün sırasıyla alt ve üst sınırlarını göstermekte olup; yerel zemin koşullarına göre değişmektedir.

7) Son adımda, $S_{a}$ değerleri Şekil 5'de verilen formülasyonlar ile hesaplanıp şekilde görülen tasarım ivme spektrumu çizilir. Bu şekilde $T_{L}$ değeri ise uzun periyoda geçiş noktasını göstermektedir ve bu değerler ilgili yönetmelikte bulunan haritalardan (ASCE/SEI 7-10'daki Şekil (22-12) (22-16)'da) coğrafi konuma bağlı olarak elde edilir.

$S_{I}$ ve $S_{S}$ katsayılarının sırasıyla $0.6 \mathrm{~g}$ ve $1.5 \mathrm{~g}$ alınması durumunda tasarım ivme spektrumları Şekil 6'daki gibi elde edilebilir. Görüldügüü üzere spektral ivme değerleri, spektrumun azalan kısmında (sabit hız bölgesi) referans zemin sınıfı olan B'ye göre (DBYBHY2007'de Z2 ve UBC97'de SB zemin sınıfına denk gelmektedir) daha kötü olan zeminler için (C, D ve E) daha fazla iken, daha iyi olan zemin (A) için ise daha düşük kalmaktadır. DBYBHY2007'dekine benzer şekilde, zemin kötüleştikçe sabit-ivme bölgesi genişlemekte ayrıca UBC97'dekine benzer şekilde bu bölgede de spektral ivme değerleri değişmektedir. $\mathrm{Bu}$ durum, detaylı bir şekilde Bölüm 2.5'de incelenecektir.

1 Ocak 2019'da yürürlüğe girecek olan TBDY 2019 yönetmeliğinde kısa periyot bölgesi için ve $1.0 \mathrm{~s}$ periyot için tanımlanan yerel zemin etki katsayıları (sırasıyla $F_{s}$ ve $F_{l}$ ) Tablo 2'de verilmiş̧tir. Söz konusu katsayıların ASCE/SEI 7-10'daki karşılıklarının sunulduğu Tablo 1 ile Tablo 2'nin karşılaştırılmasından görüleceği üzere; benzer $S_{s}$ ve $S_{1}$ katsayıları ve benzer zemin sınıfları için tanımlanan $F_{a}$ veya $F_{s}$ ve $F_{v}$ veya $F_{l}$ katsayıları, TBDY2019 ve ASCE/SEI 7-10 yönetmeliklerinde hemen hemen aynı değerlere sahiptir. Spektral ivme 
formülasyonlarının da her iki yönetmelikte aynı olduğu dikkate alınırsa, ASCE/SEI 7-10 için bu çalışma kapsamında yapılan yorumların TBDY 2019 yönetmeliği için de geçerli olabileceği söylenebilir.

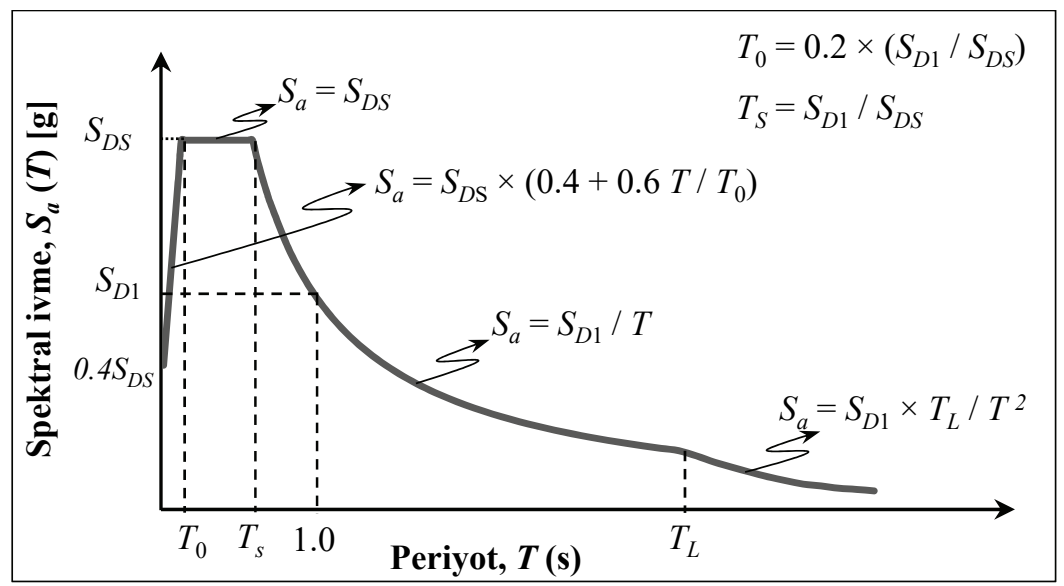

Şekil 5 - ASCE/SEI 7-10 Tasarım İvme Spektrumu.

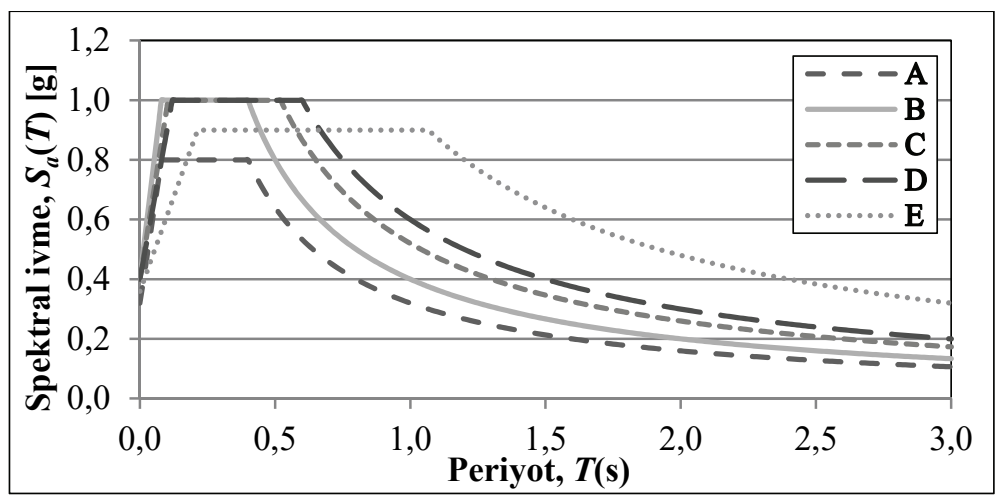

Şekil 6 - ASCE/SEI 7-10 Tasarım Ivme Spektrumlarl $\left(S_{1}=0.6 \mathrm{~g}, S_{S}=1.5 \mathrm{~g}\right)$

Tablo 2 - TBDY2019'a Göre Yerel Zemin Etki Katsayıları $F_{s}$ ve $F_{1}$.

\begin{tabular}{|c|c|c|c|c|c|c|c|c|c|c|c|c|}
\hline \multirow{2}{*}{$\begin{array}{c}\text { Zemin } \\
\text { sinıfi }\end{array}$} & $\boldsymbol{F}_{s}$ & $F_{1}$ & $F_{s}$ & $F_{1}$ & $F_{s}$ & $F_{1}$ & $F_{s}$ & $F_{1}$ & $F_{s}$ & $F_{1}$ & $F_{s}$ & $F_{1}$ \\
\hline & $S_{s} \leq 0.25$ & $S_{1} \leq 0.1$ & $S_{\mathrm{s}}=0.5$ & $S_{1}=0.2$ & $S_{\mathrm{s}}=0.75$ & $S_{1}=0.3$ & $S_{s}=1.0$ & $S_{1}=0.4$ & $S_{s}=1.25$ & $S_{1}=0.5$ & $S_{s} \geq 1.5$ & $S_{1} \geq 0.6$ \\
\hline ZA & 0.8 & 0.8 & 0.8 & 0.8 & 0.8 & 0.8 & 0.8 & 0.8 & 0.8 & 0.8 & 0.8 & 0.8 \\
\hline ZB & 0.9 & 0.8 & 0.9 & 0.8 & 0.9 & 0.8 & 0.9 & 0.8 & 0.9 & 0.8 & 0.9 & 0.8 \\
\hline $\mathbf{Z C}$ & 1.3 & 1.5 & 1.3 & 1.5 & 1.2 & 1.5 & 1.2 & 1.5 & 1.2 & 1.5 & 1.2 & 1.4 \\
\hline ZD & 1.6 & 2.4 & 1.4 & 2.2 & 1.2 & 2.0 & 1.1 & 1.9 & 1.0 & 1.8 & 1.0 & 1.7 \\
\hline $\mathbf{Z E}$ & 2.4 & 4.2 & 1.7 & 3.3 & 1.3 & 2.8 & 1.1 & 2.4 & 0.9 & 2.2 & 0.8 & 2.0 \\
\hline $\mathbf{Z F}$ & & & & Sah & 1 & 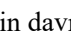 & & 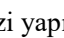 & aktır. & & & \\
\hline
\end{tabular}




\subsection{Referans Zeminler Z2, SB ve B için Tasarım İvme Spektrumlarının Karşılaş̧ırılması}

Bu çalışmada ele alınan prototip binaların referans tasarımında kullanılacak olan Z2, SB ve B türü referans zeminler için sırasıyla DBYBHY2007, UBC97, ASCE/SEI 7-10'a göre elde edilen ve sırasıyla Şekil 2, 4 ve 6'da görülebilecek olan spektrumlar Şekil 7'de karşılaştırmalı olarak sunulmuştur. Şekil 7'de görüldüğü gibi, UBC97 ve ASCE/SEI 7-10 spektrum eğrileri arasında fark yoktur. DBYBHY2007 spektrum eğrisi ise UBC97 ve ASCE/SEI 7-10'dan biraz farklı olup; sabit-hız bölgesinde bir miktar daha yüksek değerler almakla birlikte, netice itibariyle, üç farklı spektrum eğrisi de referans zemin sınıfları (Z2, SB ve B) için birbirlerine oldukça yakındır. Asıl farklılıklar diğer zemin sınıfları için mevcut olup; Bölüm 2.5'de bu farklılıklar detaylı olarak ortaya konmaktadır.

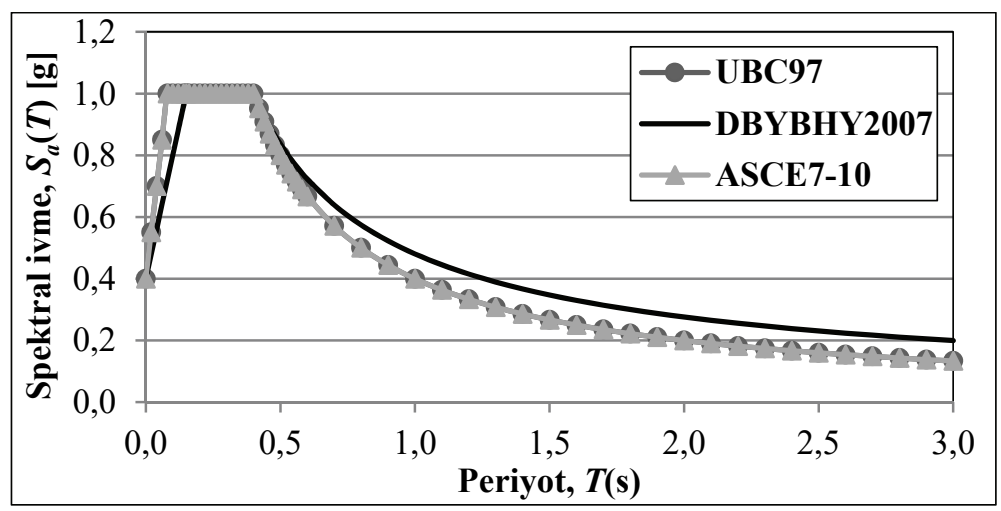

Şekil 7 - ASCE/SEI 7-10, UBC97 ve DBYBHY2007'de Strasıyla B, $S_{B}$ ve Z2 Zemin Sinıflarl Íçin Tasarım Ivme Spektrumları $\left(S_{I}=0.6 \mathrm{~g}, S_{S}=1.5 \mathrm{~g}, Z=0.4, N_{a}=N_{v}=1, A_{0}=0.4, I=1\right)$

\subsection{Zemin Büyütme Katsayılarının Karşılaştırılması}

Zemin büyütme katsayıları UBC97 şartnamesinde açıkça tarif edilmemiş olmakla birlikte sismik katsayıların içinde bir çarpan olarak yer almakta olup, dördüncü deprem bölgesi ( $Z=0.4$ ) için $N_{a}=N_{v}=1$ olduğu durumda $C_{a}$ ve $C_{v}$ değerlerinin 0.4 'e bölünmesi durumunda ortaya çıkan değerlerdir. Tablo 3 'de verilen bu değerlerin $\left(C_{a} / 0.4\right.$ ve $\left.C_{v} / 0.4\right)$ ASCE/SEI 710 'da açıkça tarif edilmiş olan zemin katsayıları $F_{a}$ ve $F_{v}$ 'ye yaklaşı olarak eşit olduğu görülmektedir. DBYBHY2007'de zemin büyütme katsayıları açıkça tarif edilmediğinden bu çalışmaya özel $B_{a}$ ve $\mathrm{B}_{v}$ olarak adlandırılmış olup, 1.0'a eşittir.

Tablo 3'deki katsayılara bakıldığında, DBYBHY2007'nin zemin büyütmesini uygun şekilde dikkate almadığı ve bu açıdan güvensiz olabileceği düşünülebilir. Ancak, bu etkinin DBYBHY2007'de spektruma bir çarpan olarak etki eden açıkça tanımlanmış katsayılarla değil, spektrum formülasyonunun içerisinde gizli olarak yer aldığını ortaya koyabilmek ve adil bir karşılaştırma yapabilmek için UBC97, ASCE/SEI 7-10 ve DBYBHY2007'de bulunan tüm tasarım spektral ivme değerleri $\mathrm{Z2}$ referans zemine ait spektral ivme değerlerine bölünerek bu çalışmaya özel zemin büyütme katsayısı $\left(B_{k}\right)$ elde edilmiştir. 
Tablo 3 - Farklı Yönetmeliklerdeki Zemin Büyütme Katsayıları $\left(S_{1}=0.6 \mathrm{~g}, S_{S}=1.5 \mathrm{~g}, Z=0.4, N_{a}=N_{v}=1, A_{0}=0.4\right)$

\begin{tabular}{|c|c|c|c||c|c|c|}
\hline \multirow{2}{*}{$\begin{array}{c}\text { Zemin } \\
\text { sinıfi }\end{array}$} & UBC97 & $\begin{array}{c}\text { ASCE/SEI 7- } \\
\mathbf{1 0}\end{array}$ & DBYBHY2007 & UBC97 & $\begin{array}{c}\text { ASCE/SEI 7- } \\
\mathbf{1 0}\end{array}$ & DBYBHY2007 \\
\cline { 2 - 7 } & $\mathbf{Z = 0 . 4}$ & $\mathbf{S}_{\mathbf{s}} \geq \mathbf{1 . 2 5}$ & $\mathbf{A}_{\mathbf{0}}=\mathbf{0 . 4}$ & $\mathbf{Z}=\mathbf{0 . 4}$ & $\mathbf{S}_{\mathbf{1}} \geq \mathbf{0 . 5}$ & $\mathbf{A}_{\mathbf{0}}=\mathbf{0 . 4}$ \\
\cline { 2 - 7 } & $\mathbf{C}_{\mathbf{a}} / \mathbf{0 . 4}$ & $\mathbf{F}_{\mathbf{a}}$ & $\mathbf{B}_{\mathbf{a}}$ & $\mathbf{C}_{\mathbf{v}} / \mathbf{0 . 4}$ & $\mathbf{F}_{\mathbf{v}}$ & $\mathbf{B}_{\mathbf{v}}$ \\
\hline A veya $\mathbf{S}_{\mathbf{A}}$ & 0.8 & 0.8 & 1.0 & 0.8 & 0.8 & 1.0 \\
\hline B veya $\mathbf{S}_{\mathbf{B}}$ & 1.0 & 1.0 & 1.0 & 1.0 & 1.0 & 1.0 \\
\hline C veya $\mathbf{S}_{\mathbf{C}}$ & 1.0 & 1.0 & 1.0 & 1.4 & 1.3 & 1.0 \\
\hline D veya $\mathbf{S}_{\mathbf{D}}$ & 1.1 & 1.0 & 1.0 & 1.6 & 1.5 & 1.0 \\
\hline E veya $\mathbf{S}_{\mathbf{E}}$ & 0.9 & 0.9 & 1.0 & 2.4 & 2.4 & 1.0 \\
\hline
\end{tabular}

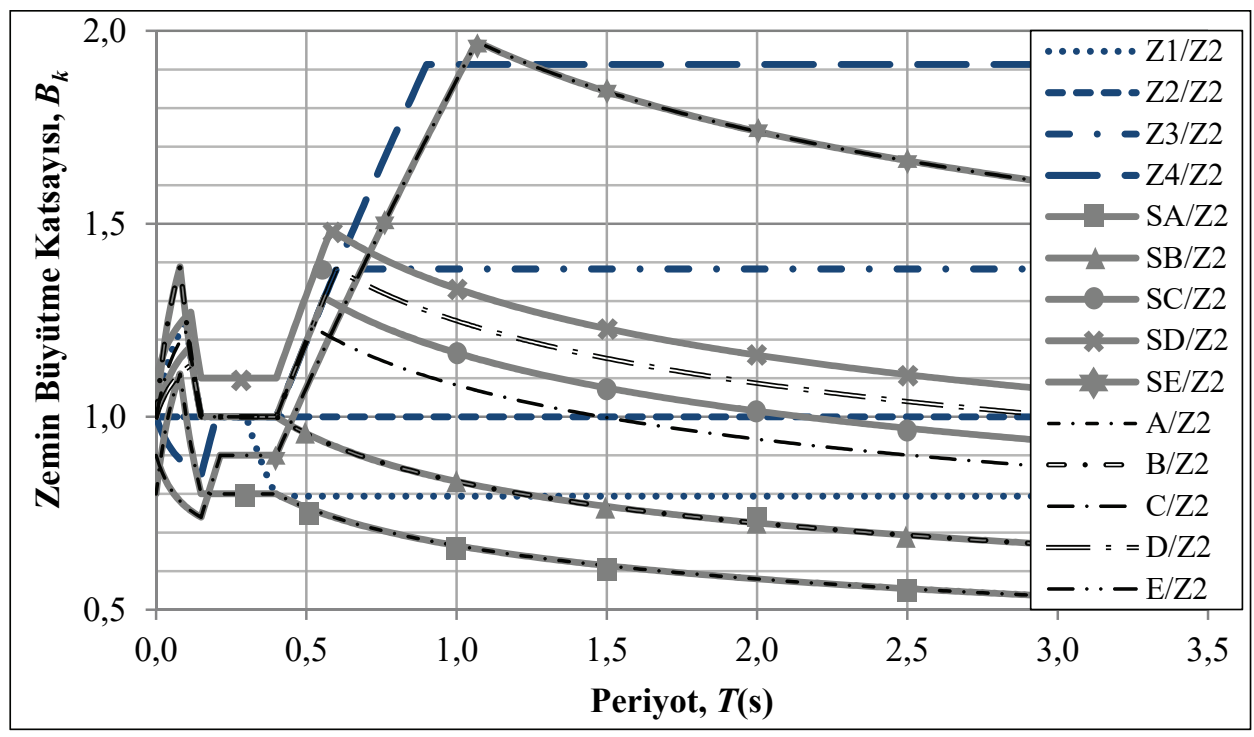

Şekil 8 - ASCE/SEI 7-10, UBC97 ve DBYBHY2007'deki Farklı Zemin Sınıfları Için Z2 Spektrum Değerlerine Göre Büyütmeyi Gösteren Zemin Büyütme Katsayllarl, $B_{k}\left(S_{1}=0.6 g, S_{S}=1.5 g, Z=0.4, N_{a}=N_{v}=1, A_{0}=0.4\right)$

Şekil 8, irdelenen zemin sınıflarına ait spektral ivme değerlerinin, Z2 referans zemin sınıfına ait spektral ivme değerlerinin kaç katı olduğunu farklı periyot değerleri için göstermekte olup; bu şekilde $B_{k}$ katsayılarının aldığı değerler farklı zemin sınıfları için karşılaştırmalı olarak verilmiştir. Z2'ye göre normalize edilerek elde edilen bu zemin büyütme katsayıları incelendiğinde, örneğin Z4 için hesaplanan zemin büyütme katsayısının (Z4/Z2), D ve SD için elde edilenin (D/Z2 ve $\mathrm{SD} / \mathrm{Z2})$ çok üzerinde, $\mathrm{E}$ ve $\mathrm{SE}$ için hesaplananların (E/Z2 ve $\mathrm{SE} / \mathrm{Z} 2)$ ise geniş bir periyot aralığında üzerinde kaldığı görülmektedir. Yani, DBYBHY2007'nin zemin büyütme etkisini uzun periyotlu yapılar için (sabit hız bölgesinde) aslında dolaylı olarak ciddi bir şekilde dikkate aldığı ve diğer Amerikan yönetmeliklerine ve 
TBDY 2019'a göre daha yüksek spektral ivme değerleri öngördüğü ortaya çıkmıştır. Ancak, sabit ivme bölgesinde durum böyle değildir; yani DBYBHY2007 zemin büyütme etkisini bu kısımlarda UBC97 veya ASCE/SEI 7-10 ve TBDY 2019 yönetmeliklerindeki gibi dikkate almamakta ve spektral ivme değerleri bu yönetmeliklerdekilerin altında kalabilmektedir.

\section{YÖNTEM}

$\mathrm{Bu}$ çalışma kapsamında, Giriş bölümünde ortaya konan amaç doğrultusunda, farklı kat sayılarına sahip prototip betonarme binalar farklı zemin sınıfları için oluşturulan DBYBHY2007 [1], UBC97 [2] ve ASCE/SEI 7-10 [3] tasarım ivme spektrumları kullanılarak tasarlanmış ve tasarlanan bu binaların betonarme taşıyıcı sistemlerinin maliyetleri ile tarihi dört örnek deprem kaydı altındaki performans potansiyelleri karşılaştırılmıştır [23].

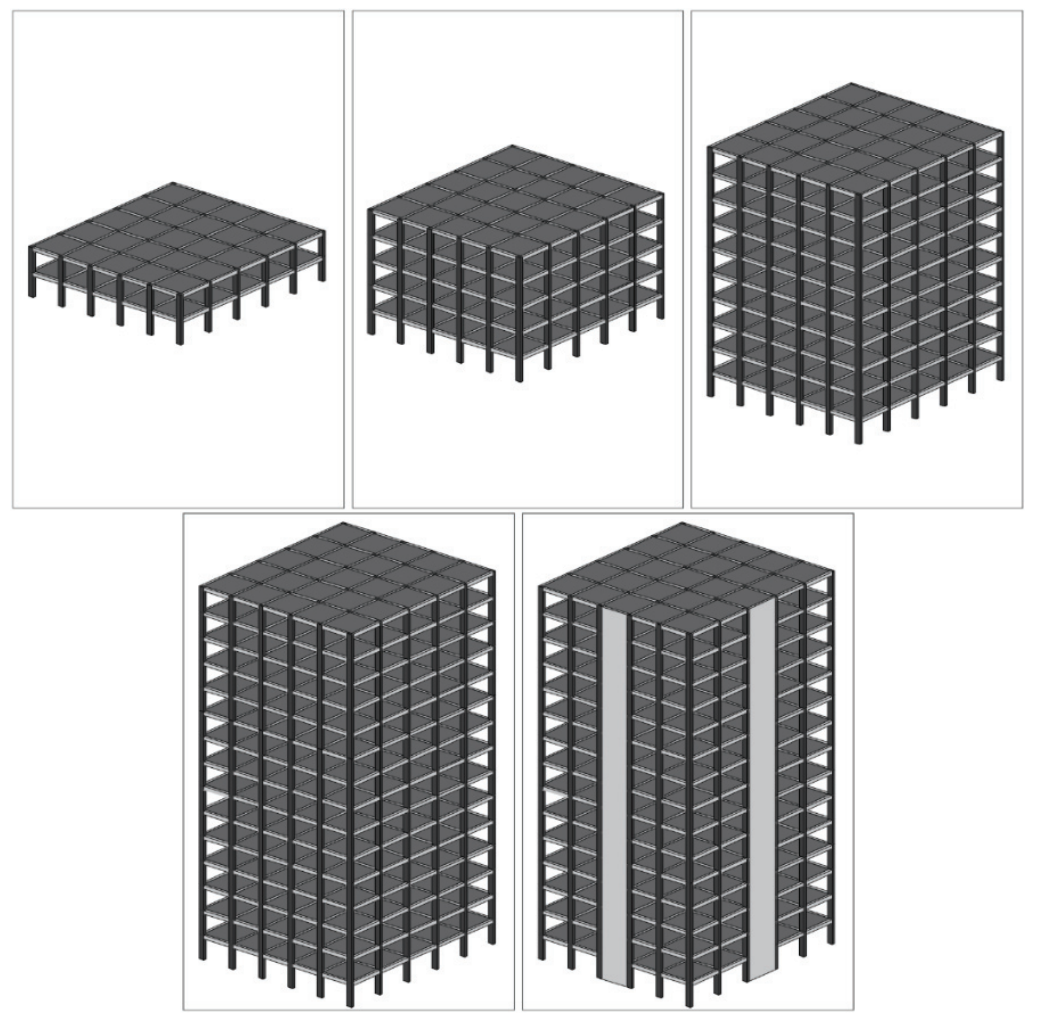

Şekil 9 - 2, 5, 10 ve 15 Katll Prototip Bina Modellerinin Üç Boyutlu Görünüşleri.

Bu çalışmada kullanılan prototip modellere ait geometrik özellikler Benmokhtar, 2014 [24] çalışmasındaki yapısal modelden alınmıştır. Buna göre, aynı tipik kat planına sahip dört farklı yükseklikte $(2,5,10$ ve 15 katlı) ve taşıyıcı sistemleri betonarme çerçeve olan dört adet prototip bina ele alınmıştır. Sadece 15 katlı bina, ayrıca çerçeve-perde taşıyıcı sisteme sahip 
olacak şekilde de modellenmiş ve tasarlanmıştır. Binaların kat planları simetriktir ve aks sayısı ile açıklıkları da yüksekliği en fazla olan bina modelinde dahi yapı narinliği 2'yi geçmeyecek şekilde tüm binalar için aynıdır. Her iki yatay eksen doğrultusunda da $5 \mathrm{~m}$ aralıklarla 6 adet aks bulunan tipik kat planlarına sahip binalar için tipik kat yüksekliği ise $h_{\mathrm{i}}=3 \mathrm{~m}$ olarak tanımlanmıştır. Ne planda ne de düşeyde herhangi bir düzensizlik bulunmamaktadır. Bu binalara ait üç boyutlu görünüşler, Şekil 9'da verilmiştir.

Tüm tasarımlar, DBYBHY2007 [1] ve TS500'deki [25] kurallar doğrultusunda bir tasarım programı [26] yardımıyla yapılmıştır, ancak sonraki kısımlarda detayları anlatılan farklı tasarımlarda kullanılan tasarım ivme spektrumları farklı olup DBYBHY2007 [1], UBC97 [2] ve ASCE/SEI 7-10'dan [3] alınmıştır. Tasarımlar, modal spektral analiz yöntemi ile yapılmıştır; ancak daha sonra temsili dört tarihi deprem kaydı altında farklı tasarımların sismik analizleri, zaman-tanım alanı analizi yöntemi kullanılarak da gerçekleştirilmiştir.

Tablo 4 - Deprem Kayıtlarının Özellikleri

\begin{tabular}{|c|c|c|c|c|}
\hline Deprem ve Tarihi & İstasyon ve Kayıt Adı & $\begin{array}{c}\text { Yer } \\
\text { Hareketi } \\
\text { Kodu }\end{array}$ & $\begin{array}{c}\text { Faya olan } \\
\text { en yakın uzaklık } \\
\text { (km) }\end{array}$ & $\begin{array}{c}\text { Pik Yer } \\
\text { İvmesi (g) }\end{array}$ \\
\hline $\begin{array}{c}\text { Darfield New Zealand } \\
2010\end{array}$ & $\begin{array}{c}\text { Pages Road Pumping Station } \\
\text { PRPCS }\end{array}$ & PRP & 24.55 & 0.223 \\
\hline $\begin{array}{c}\text { E1 Mayor-Cucapah } \\
2010\end{array}$ & $\begin{array}{c}\text { Michoacan De Ocampo } \\
\text { MDO090 }\end{array}$ & MD & 15.91 & 0.408 \\
\hline $\begin{array}{c}\text { Cape Mendocino } \\
1992\end{array}$ & $\begin{array}{c}\text { Fortuna Fire Station } \\
\text { FFT360 }\end{array}$ & FFT & 20.41 & 0.283 \\
\hline $\begin{array}{c}\text { Coalinga-01 } \\
1983\end{array}$ & $\begin{array}{c}\text { Cantua Creek School } \\
\text { H-CAK270 }\end{array}$ & CCS & 24.02 & 0.225 \\
\hline
\end{tabular}
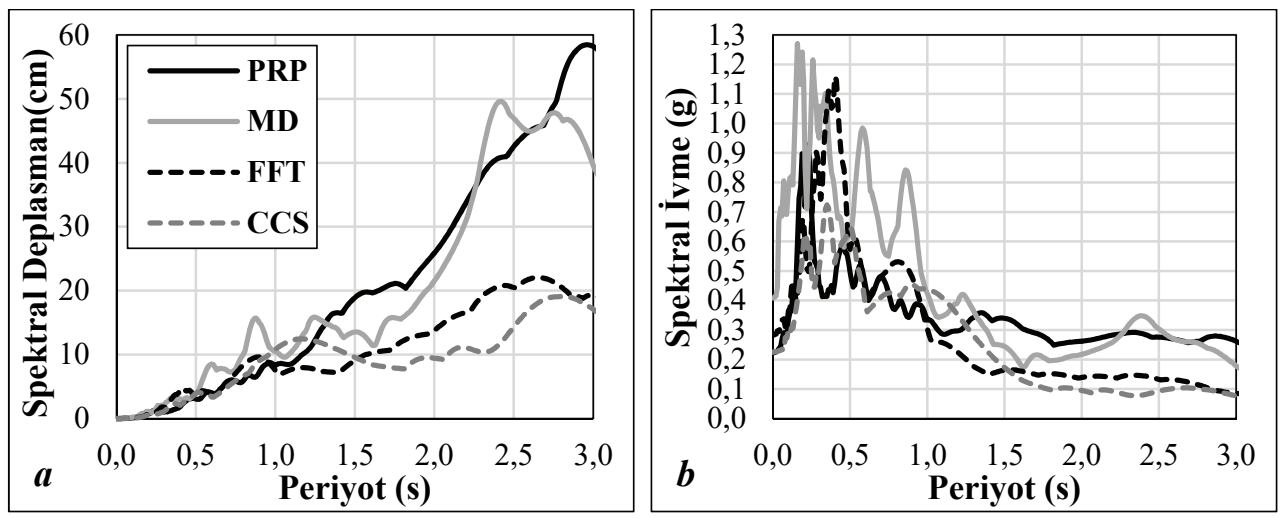

Şekil 10 - Deprem Kayıtlarına Ait \%5 Sönümlü Spektrumlar: (a) Deplasman ve (b) İvme.

Söz konusu zaman-tanım alanı analizlerinde kullanılmak üzere, incelenen üç yönetmelikte de ortak olarak en kötü zemin sınıfına giren bir zeminde (UBC97'de SD) kaydedilmiş, yakın- 
fay etkilerini içermeyen (faya uzaklık mesafesi $15 \mathrm{~km}$ 'den fazla) kayıtlar (Bkz. Tablo 4) seçilmiş ve pik yer ivmeleri yönetmeliklerin birinci derece deprem bölgeleri (UBC97'de 4 . Derece deprem bölgesi) için tanımlanan yer ivmesi katsayısı $(=0.4)$ ile uyumlu olacak şekilde $0.4 \mathrm{~g}$ 'ye ölçeklendirilerek zaman-tanım analizlerinde kullanılmıştır. Bu kayıtlar, Berkeley Üniversitesi'nin PEER-NGA [27] Ground Motion data bankasından indirilmiştir. Söz konusu yer hareketi kayıtlarının $V_{s, 30}$ değerleri 206 ile $355 \mathrm{~m} / \mathrm{s}$ aralığındadır. Bu deprem kayıtlarına ait spektral deplasman ve spektral ivme grafikleri \%5 sönüm için sırasıyla Şekil 10a ve b'de verilmiştir.

\section{ANALIZLER VE BULGULAR}

\subsection{Farklı Spektrumlara Göre Analiz ve Tasarım}

$\mathrm{Bu}$ çalışma kapsamında, çerçeve sisteme sahip kat adetleri farklı 4 adet binanın 14 farklı spektruma göre analizi ve tasarımı gerçekleştirilmiş olup toplamda 56 farklı bina tasarımı yapılmıştır. Buna ek olarak, sadece en kötü zeminlerin ele alındığı durumlar için 15 katlı bina ayrıca perdeli-çerçeveli sistem olarak da ele alınmış ve 3 ek tasarım daha yapılmıştır.

Öncelikle Z2 referans tasarımı gerçekleştirilmiştir. $12 \mathrm{~cm}$ kalınlığındaki bir döşeme için “DBYBHY2007'deki 0.02 göreli kat öteleme oranı sınırını aşmayacak şekilde mümkün olan en küçük yapısal eleman boyutlarının kullanılması” kriteri kullanılarak elde edilen ' Z2'ye göre optimum tasarım" Tablo 5'de verilmiştir [24]. Dolayısıyla, Tablo 5'de rapor edilen boyutlar, uygulamada kullanılabilecek 5 ve 5 'in katları $(35 \mathrm{~cm}, 40 \mathrm{~cm}, 45 \mathrm{~cm}$, vs.) yerine, herhangi bir yuvarlama yapılmaksızın burada yürütülen teorik çalışmanın kriterlerine uygun boyutlardır. Ayrıca, söz konusu boyutların belirlenmesinde mevcut deprem yönetmeliği DBYBHY2007'de önerildiği gibi çatlamamış kesit özellikleri dikkate alınmıştır. Çatlamış kesit özellikleri kullanılması durumunda, uygulanacak 0.02 göreli kat öteleme oranı sınırı nedeniyle eleman boyutlarının incelenen tüm durumlar için büyümesi ve daha büyük boyutlar çatlamış kesit özellikleri ile birlikte kullanıldığında da, aşağıda ortaya konan göreli kat ötelemesi ve kat deplasmanları sonuçlarının benzer eğilimler göstermesi beklenir.

Tablo 5 - Z2 Tasarım İvme Spektrumu İçin 2,5,10 ve 15 Katlı Binaların Optimum Tasarım Boyutlarl [cm]

\begin{tabular}{|c|c|c|c|c|c|c|c|}
\hline Bina türü & $\mathbf{2}$ katlı & $\mathbf{5}$ katlı & \multicolumn{2}{|c|}{$\mathbf{1 0}$ katlı } & \multicolumn{3}{|c|}{$\mathbf{1 5}$ katlı } \\
\hline Kat No & $\mathbf{1 - 2}$ & $\mathbf{1 - 5}$ & $\mathbf{1 - 5}$ & $\mathbf{6 - 1 0}$ & $\mathbf{1 - 5}$ & $\mathbf{6 - 1 0}$ & $\mathbf{1 1 - 1 5}$ \\
\hline Döşeme kalınlığı & 12 & 12 & 12 & 12 & 12 & 12 & 12 \\
\hline Kiriş boyutları & $25 \times 36$ & $25 \times 36$ & $25 \times 36$ & $25 \times 36$ & $32 \times 36$ & $31 \times 36$ & $25 \times 36$ \\
\hline Kolon boyutu & $36 \times 36$ & $36 \times 36$ & $42 \times 42$ & $35 \times 35$ & $54 \times 54$ & $47 \times 47$ & $36 \times 36$ \\
\hline
\end{tabular}

Farklı spektrum yüklemeleri (DBYBHY2007, UBC97 ve ASCE/SEI 7-10) altında 2, 5, 10 ve 15 katlı binalar için tasarım boyutları, benzer yöntem kullanılması ve Tablo 5'deki boyutlar üzerinde gerekli değişiklikler yapılması suretiyle elde edilmiş olup yer kısıtı nedeniyle bu boyutlar burada sunulmamıştır. Bu hususla ilgili detaylı bilgi içi Azimi, 2016'ya [23] başvurulabilir. 


\subsection{Bulgular}

Bu kısımda öncelikle Bölüm 4.1'de tasarımları yapılan 2, 5, 10 ve 15 katlı binaların taşıyıcı sistemlerinin farklı spektrum yüklemeleri için maliyet karşılaştırmaları yapılmıştır. İkinci aşamada ise sismik performans potansiyeli karşılaştırmaları, göreli kat ötelemelerinin ve en üst kat deplasmanlarının karşılaştırılması suretiyle ortaya konmuştur.

\subsubsection{Taşıyıcı Sistemlerin Kaba Maliyetinin Karşılaştırılması}

Bu çalışmada, DBYBHY2007, UBC97 ve ASCE/SEI 7-10 yönetmeliklerindeki farklı zemin sınıfları için oluşturulan spektrumlar kullanılarak yapılan taşıyıcı sistem tasarımlarının kaba maliyetleri elemanlara dayalı maliyet hesabı yöntemi kullanılarak yapılmıştır. Elemanlara dayalı maliyet hesabı yöntemine göre, çerçeveli veya çerçeveli/perdeli taşıyıcı sistemlerin taşıyıcı elemanları olan kolon, kiriş ve perdelerin toplam hacmi ile betonun birim $\mathrm{m}^{3}$ fiyatı çarpılarak toplam beton maliyeti hesaplanmıştır. Bu elemanlarda kullanılan toplam donatı maliyeti ise toplam donatı ağırlığı ile donatı birim kg fiyatı çarpılarak; kalıp maliyeti de yine bu elemanlar için toplam kalıp alanı ile kalıp birim $\mathrm{m}^{2}$ fiyatı çarpılarak hesaplanmıştır. Farklı spektral yüklemeler (Z1, Z3, Z4, SA, SB, SC, SD, SE, A, B, C, D ve E) için yapılan tasarımların maliyetlerinin Z2 tasarım maliyetine göre yüzde cinsinden farkı (artış veya azalışları) Denklem 6 yardımıyla hesaplanmış olup maliyet değerleri makalede her durum için TL cinsiden ayrı ayrı sunulmamıştır. Bu şekilde hesaplanan farkların pozitif değerleri maliyette Z2 tasarımlarına göre artışı, negatif değerleri ise azalışı ifade etmektedir. Burada belirtmek gerekir ki; maliyet hesabında boyutlara ve bina yüksekliğine bağlı olarak iskelelerin büyüklük ve özelliklerinde ortaya çıkabilecek farklılıklar gözetilmemiş olup iş sağlığı ve iş güvenliği önlemlerine bağlı ek maliyetler de göz önüne alınmamıştır.

Maliyet Fark $(\%)=\frac{\text { Maliyet }_{\text {spektrum }, i}-\text { Maliyet }_{D B Y B H Y 2007(Z 2)}}{\text { Maliyet }_{D B Y B H Y 2007(Z 2)}} \times 100$

Maliyet karşılaştırmaları 2, 5, 10 ve 15 katlı binalar için sırasıyla Şekil 11a, b, c ve d'de sunulmuştur. Şekil 11a, b, c ve d incelendiğinde, karşılaştırma için referans alınan Z2 türü zemine göre daha sağlam olan Z1 (SA ve A) türü zemin için maliyette azalma görülmektedir. Ancak maliyetteki azalma sadece 2 ve 5 katlı binalarda anlamlı mertebelerde olup 10 ve 15 katlı binalarda önemsenmeyecek kadar azdır: Daha sağlam zeminler söz konusu olduğunda, yani Z1, SA ve A spektrumları ile tasarlanan binaların Z2 spektrumu ile tasarlanan binaya göre maliyet farkı, 2 katlı binalar için sırasıly -\%6.6, -\%6.5 ve -\%6.5 (Şekil 11a), 5 katlı binalar için sırasıyla -\%7.2, -\%8.7 ve -\%8.7 (Şekil 11b), 10 katlı binalar için sırasıyla -\%0.4, -\% 0.4 ve -\%0.4 (Şekil 11c) ve 15 katlı binalar için sırasıyla -\%2.8, -\% 3.0 ve -\%3.0 (Şekil 11d) olmaktadır. 


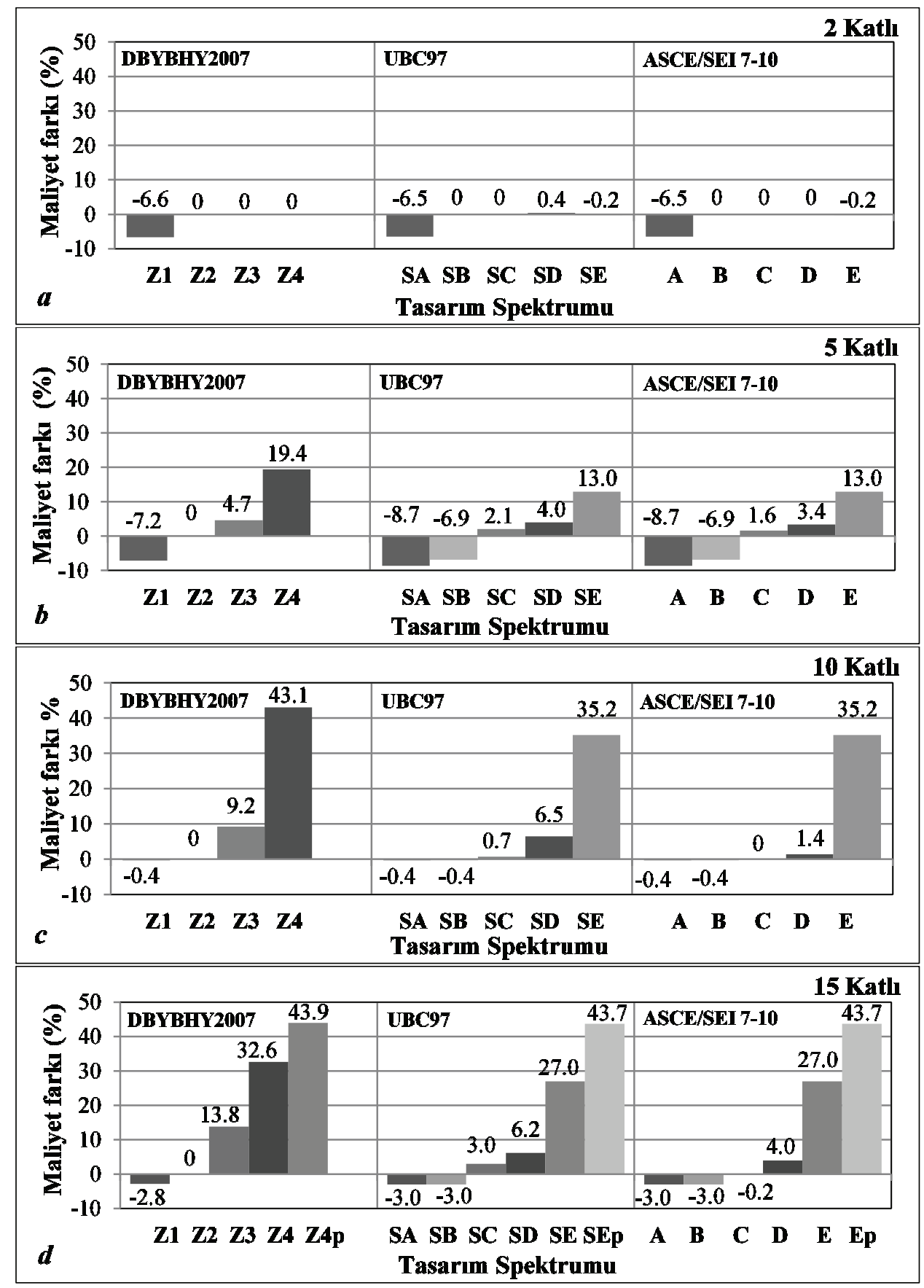

Şekil 11 - Bir Tasarım Spektrumu İçin Hesaplanan Kaba Maliyetin Z2 Spektrumu İçin Hesaplanan Kaba Maliyete Göre Farkı (Bkz. Denklem (6)) 
Z2'ye göre daha zayıf zeminler olan Z3 ve Z4; SC, SD ve SE; C, D ve E için maliyette artışlar görülmektedir. $\mathrm{Bu}$ maliyet artışları, zemin kötüleştikçe genel olarak daha belirginleşmektedir. Ayrıca, kat sayısı arttıkça daha zayıf zemin olan Z4; SD ve SE; D ve E için maliyet artışı daha da belirginleşmektedir. Kaba maliyet karşılaştırmalarının sonuçları, aşağıdaki gibi özetlenebilir:

- Şekil 11a'dan görüldüğü üzere, Z2'ye göre daha kötü zeminlere ait spektrumlar altında tasarlanan 2 katlı binaların Z2 spektrumu alında tasarlanan bir 2 katlı binaya göre maliyet fark1 neredeyse yoktur.

- Şekil 11b'den anlaşılacağı gibi, 5 katlı yapılar için, SC ve C; SD ve D spektrumları altında tasarlanan binaların Z2 spektrumu altında tasarlanan binaya göre maliyet artışı sırasıyla yaklaşık $\% 2$ ve $\% 4$ civarında olmaktadır. Z3 spektrumu altında tasarlanan binanın Z2 spektrumu altında tasarlanan binaya göre maliyet artışı da \%4.7'ye eşittir. Z2 spektrumu için tasarlanan binaya göre maliyet artışı Z4 için \%19.4 olup, SE ve E spektrumları için olan \%13.0 olan maliyet farkından büyüktür. 10 katlı yapılar için Şekil 11c'den görüldüğü üzere, SC ve C spektrumları altında tasarlanan binaların $Z 2$ spektrumu altında tasarlanan binaya göre maliyet farkı sıfıra yakındır. Ancak SD ve D spektrumları altında tasarlanan binaların Z2 spektrumu altında tasarlanan binaya göre maliyet artışı sırasıyla \%6.5 ve \%1.4 olmaktadır. Z3 zeminlerde ise, Z2'ye göre maliyet artışı \%9.2'dir. Z2 spektrumu için tasarlanan binaya göre maliyet artışı Z4 için \%43.1 olup, SE ve E spektrumları için \%35.2 olan maliyet farkından büyüktür.

- 15 katlı yapılar için Şekil 11d'den anlaşılacağı gibi, SC ve C spektrumları altında tasarlanan binaların Z2 spektrumu altında tasarlanan binaya göre maliyet farkı sırasıyla $\% 3.0$ ve $-\% 0.2$ olmaktadır. SD ve D spektrumları altında tasarlanan binaların Z2 spektrumu altında tasarlanan binaya göre maliyet farkı ise, sırasıyla \%6.2 ve \%4.0 olmaktadır. Z2 spektrumu için tasarlanan binaya göre maliyet farkı Z4 için \%32.6 olup, SE ve E spektrumları için \%27.0 olan maliyet farkından büyüktür.

- Diğer binalardan farklı olarak 15 katlı binalara özel olmak üzere çerçeve sisteme ek olarak, en kötü zeminler için perdeli-çerçeveli sistemler de tasarlanmıştır (grafiklerde " $p$ " alt indisi ile gösterilmiştir). Şekil 11d'den görüldüğü üzere, perdeli-çerçeveli sistem kullanıldığında Z4, SE ve E zeminlerinin Z2 zemine göre maliyet farkı çerçeve sistem kullanıldığında elde edilen farka göre daha büyük olmaktadır (Z2'ye göre maliyet farkları yaklaşık \%44'tür).

ASCE/SEI 7-10, UBC97 ve DBYBHY2007'deki farklı zemin sınıfları için Z2 spektrum değerlerine göre büyütmeyi gösteren bu çalışmaya özel tarif edilmiş olan zemin büyütme katsayıları, $B_{k}$, Bölüm 2'de tarif edilmiş ve Şekil 8'de sunulmuştu. Bu şeklin üzerine, bu çalışmada ele alınan tüm yapıların doğal periyotları işaretlenerek Şekil 12'de tekrar sunulmuştur. Şekil 12'den, farklı yapılar ve farklı zemin koşulları için $B_{k}$ 'nın 1.0 değerinden farklı miktarlarda saptığı görülmektedir. $\mathrm{Bu}$ durum, yukarıda ortaya konan maliyet karşılaştırmaları ile birlikte değerlendirildiğinde, $B_{k}=1.0$ 'dan sapma miktarı arttıkça maliyet farkının arttı̆̆ı sonucuna ulaşılmaktadır. 


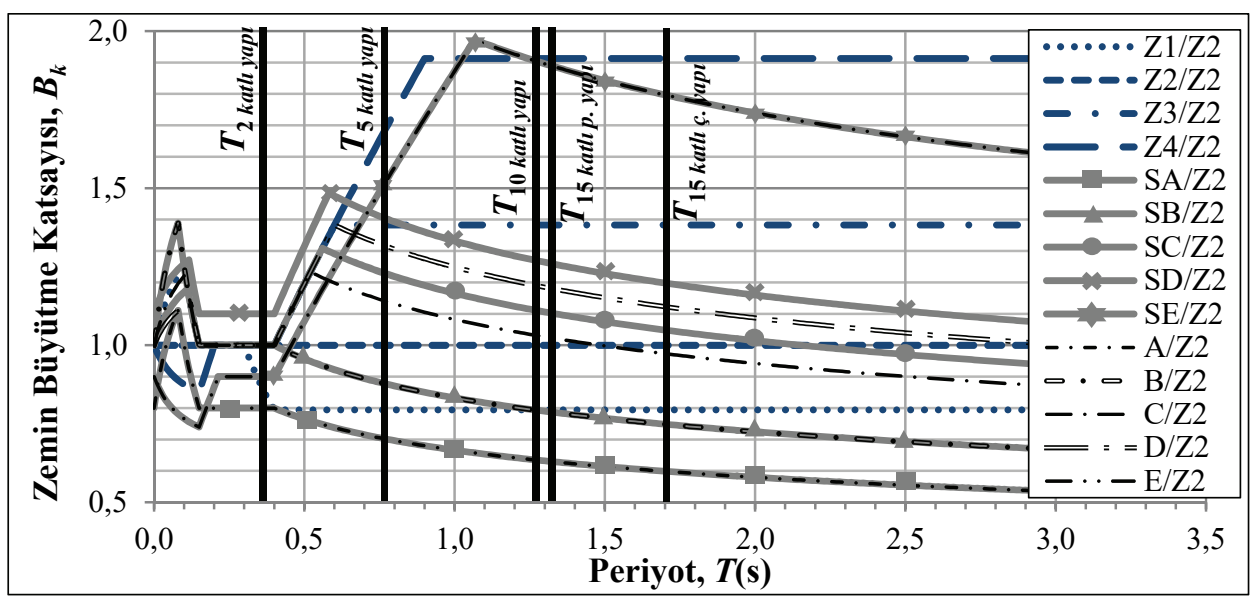

Şekil 12 - Zemin Büyütme Katsayllarl $\left(S_{I}=0.6 g, S_{S}=1.5 g, Z=0.4, N_{a}=N_{v}=1, A_{0}=0.4\right)$ ve Prototip Binaların Periyotları (Bina periyotları Z4, SE ve E tasarımlarına aittir).

\subsection{Spektral Analize Göre Sismik Performans Potansiyellerinin Karşılaştırılması}

Göreli kat ötelemesi oranları (göreli kat ötelemelerinin kat yüksekliklerine oranı) ve en üst kat deplasmanları birer kriter olarak ele alınmak suretiyle sismik performans potansiyeli değerlendirmelerinin yapıldığı bu kısımdaki analizler, Bölüm 4.1'de detayları verilen modeller kullanılarak gerçekleştirilmiştir. Bu kısımda, Z1, Z2, Z3 ve Z4'e göre yapılan tasarımlar sırasıyla $Z 1, Z 2, Z 3$ ve $Z 4$ deprem tasarım spektrumlarına maruz bırakılmış $\left(Z 1_{Z 1}\right.$, $\mathrm{Z2}_{\mathrm{Z} 2}, \mathrm{Z}_{\mathrm{Z} 3}, \mathrm{Z4}_{\mathrm{Z} 4}$ ); SA, SB, SC, SD ve SE'ye göre yapılan tasarımlar sırasıyla SA, SB, SC, $\mathrm{SD}$ ve $\mathrm{SE}$ deprem tasarım spektrumlarına maruz bırakılmış $\left(\mathrm{SA}_{\mathrm{SA}}, \mathrm{SB}_{\mathrm{SB}}, \mathrm{SC}_{\mathrm{SC}}, \mathrm{SD}_{\mathrm{SD}}, \mathrm{SE}_{\mathrm{SE}}\right)$ ve $A, B, C, D$ ve E'ye göre yapılan tasarımlar sirasıyla $A, B, C, D$ ve $E$ deprem tasarım spektrumlarına maruz bırakılmış $\left(\mathrm{A}_{\mathrm{A}}, \mathrm{B}_{\mathrm{B}}, \mathrm{C}_{\mathrm{C}}, \mathrm{D}_{\mathrm{D}}, \mathrm{E}_{\mathrm{E}}\right)$ olup Şekil 13 - 16'da sunulan grafikler bu durum dikkate alınarak değerlendirilmelidir. Burada incelenecek göreli kat ötelemeleri etkin göreli kat ötelemeleri $\left(\delta_{\mathrm{i}}\right)$ olup, bir i. kat için bu değer, yapı davranış katsayısı $R$ ile azaltılmış deprem yükleri için hesaplanan göreli kat ötelemesi $\Delta_{i}$ değerinin $R$ ile çarpılmasıyla elde edilir: $\delta_{\mathrm{i}}=R \times \Delta_{i}$. Benzer şekilde, burada incelenecek en üst kat deplasmanı $(N$. kat deplasmanı) etkin deplasman $(d N)$ olup bu değer, $R$ ile azaltılmıs deprem yükleri için hesaplanan en üst kat deplasmanı $D N$ değerinin $R$ ile çarpılmasıyla elde edilir: $d N=R \times D N$. Karşılaştırmalar, etkin göreli kat ötelemeleri oranları $\left(\delta_{\mathrm{i}} / h_{\mathrm{i}}\right)$ ve etkin en üst kat deplasmanı $(d N)$ baz alınarak gerçekleştirilmiştir. Grafiklerde etkin göreli kat öteleme oranları için üst sınır olarak DBYBHY2007 tarafından belirlenen üst sınır olan $\left(\delta_{\mathrm{i}} / h_{\mathrm{i}}\right)_{\max }=0.02$ alınmıştır. En üst kat deplasmanı için ise üst sınır olarak Sindel ve diğ, 1995 [28] tarafından pratik gözlemler ve farklı ülkelere ait çok sayıda deprem yönetmeliğinin incelenmesi sonucunda tanımlanmış sınır olan, $H$ bina toplam yüksekliği olmak üzere, $d N_{\max }=0.0007 \times R \times H$ dikkate alınmıştır. Bu çalışmada kullanılan yüksek süneklikli betonarme çerçeveler için $R=$ 8 olduğundan $d N_{\max }=0.0056 \times \mathrm{H}$ olup $2,5,10$ ve 15 katlı binalar için sirasıyla, $H=6,15$, 30 ve 45 m olduğundan sirasıyla $d 2_{\max }=3.36 \mathrm{~cm}, d 5_{\max }=8.4 \mathrm{~cm}, d 10_{\max }=16.8 \mathrm{~cm}$ ve $d 15_{\max }$ $=25.2 \mathrm{~cm}$ olarak hesaplanmıştır. Perdeli-çerçeveli sistem için $R=7$ olarak dikkate alındığından $d N_{\mathrm{p}, \max }=0.0049 \times H$ eşitliğinden $d 15_{\mathrm{p}, \max }=22.05 \mathrm{~cm}$ olarak hesaplanmıştır. 2 , 
5, 10 ve 15 katlı binalar için sırasıyla Şekil 13,14, 15 ve 16 incelendiğinde şu tespitler yapilabilir:

- 2 katlı binalar için (Şekil 13), farklı tasarım ve spektrum yüklemesi durumlarında elde edilen etkin göreli kat ötelemesi oranları yaklaşık aynıdır. Tasarım kriterine uygun olarak hiçbir durumda 0.02 sınırını aşmamış olup bu sınırın çok altında kalmıştır. Dolayısıyla, bu az katlı yapılar için tasarım boyutlarının belirlenmesinde göreli kat ötelemesi oranı sınırı haricindeki kriterlerin (örneğin minimum boyutların) etkin olduğu anlaşılmaktadır. Öte yandan, en üst kat deplasmanları Sindel ve diğ, 1995 [28] tarafından önerilen $d 2_{\max }=3.36$ cm sınırını bir miktar geçerek yaklaşık 4 cm civarına ulaşmıştır. Yani, DBYBHY2007'de ortaya konulan etkin göreli kat ötelemesi oranı sınırına göre yeterli olan 2 katlı binaların, Sindel ve diğ, 1995 [28] tarafından önerilmiş olan en üst kat deplasmanı sınırlarını az da olsa aştığı görülmektedir.

- 5, 10 ve 15 katlı binalar için sırasıyla Şekil 14, 15 ve 16 incelendiğinde, farklı tasarımlar ve spektrum yüklemeleri için elde edilen etkin göreli kat ötelemesi oranlarının hiçbir durumda DBYBHY2007'de ortaya konulan 0.02 sınırını geçmediği, ancak zayıf zeminlere (Z4, SE ve E) ait spektrum yüklemeleri altında, ilgili zeminlere göre yapılmış olan tasarımların 0.02 sınırına dayandığı görülmektedir. Yani, daha iyi zeminler için yapılmış olan tasarımlar bu spektrum yüklemelerine maruz kalacak olsa, 0.02 sınırının aşılabileceği anlaşılmaktadır. Bu tür bir yükleme durumu daha sonra Bölüm 4.3.1'de irdelenecektir. 5, 10 ve 15 katlı binalar için hiçbir durumda 0.02 göreli kat ötelemesi sınırı aşılmamasına rağmen bu tasarımlar, Sindel ve diğ, 1995 [28] tarafindan 5, 10 ve 15 katlı binalar için önerilen sirasiyla d5max $=8.4 \mathrm{~cm}, \mathrm{~d} 10 \max =16.8 \mathrm{~cm}, \mathrm{~d} 15 \mathrm{max}=25.2 \mathrm{~cm}$ sınırlarını aşmıştır. Daha zayıf zemine doğru gidildikçe, bu zemin sınıfları için oluşturulan ve zemin büyütme katsayıları ile büyütülmüş spektrumlara göre tasarlandıklarından daha rijit yapılar söz konusu olmasına rağmen, bu zemin sınıfları ile uyumlu spektral yüklemeler altında sınırlar çok daha fazla aşılmış ve deplasmanlar ilgili sınırın yaklaşık iki buçuk katına kadar çıkmıştır. Yani, zemin büyütmesi dikkate alınmadan daha iyi zeminler için oluşturulan tasarım spektrumlarına göre yapılan tasarımlar bu zayıf zeminler için oluşturulan spektrumlara maruz kalacak olsa, en üst kat deplasmanı sınırının çok daha fazla aşılabileceği değerlendirilebilir. Bu tür bir yükleme durumu daha sonra Bölüm 4.3.1'de irdelenecektir.

- Ayrıca, her üç yönetmeliğin en zayıf zeminlerinde (Z4, SE ve E) 15 katlı binalar perdeliçerçeveli sistem olarak da tasarlanmış olup etkin göreli kat ötelemesi oranları ve etkin en üst kat deplasmanları açısından çerçeveli sistem ile kıyaslaması Şekil 17'de sunulmuştur: Z4, SE ve E tasarım spektrumlarına göre tasarlanıp aynı spektrumlara maruz bırakılan çerçeveli sistemlerde $\left(\mathrm{Z}_{\mathrm{C} Z 4}, \mathrm{SE}_{\mathrm{C} S E}, \mathrm{E}_{\mathrm{C} E}\right)$ etkin göreli kat ötelemesi oranları 0.02 sınırını zorlamış olup, perdeli-çerçeveli sistemlerde $\left(Z 4_{\mathrm{PZ}}, \mathrm{SE}_{\mathrm{PSE}}, \mathrm{E}_{\mathrm{PE}}\right)$ ise çerçeveli sistemlere göre çok daha küçük seviyelerde kalmıştır. Ayrıca, Sindel ve diğ, 1995 [28] tarafindan önerilen $d 15_{\max }=25.2 \mathrm{~cm}$ en üst kat deplasmanı sınırı Z4, SE ve E tasarım spektrumlarına göre tasarlanan ve bu spektrumlara maruz birakılan çerçeveli binalarda $\left(Z 4_{C \zeta Z}, S_{C S E}, E_{C \zeta E}\right)$ yaklaşık 70 cm'ye ulaşmış olmasına karşın, perdeli-çerçeveli sistemler (Z4 $\left.4_{\mathrm{PZ} 4}, \mathrm{SE}_{\mathrm{PSE}}, \mathrm{E}_{\mathrm{PE}}\right)$ $d 15_{\mathrm{p}, \max }=22.05 \mathrm{~cm}$ sınırını geçmekle birlikte etkin en üst kat deplasmanları $50 \mathrm{~cm}$ 'nin altında kalarak daha iyi bir performans sergilemişlerdir (Şekil 17). 

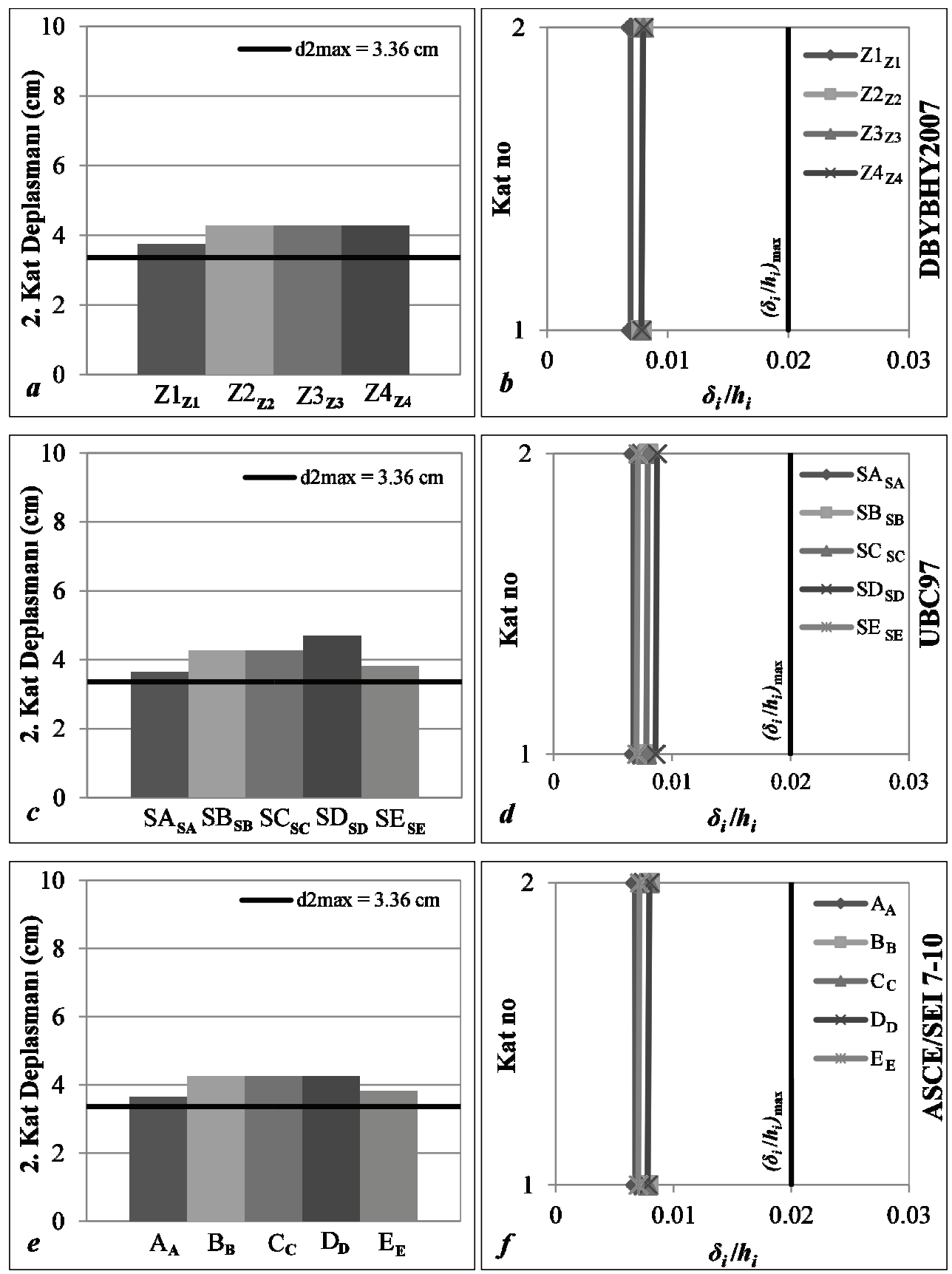

Şekil 13 - Farklı Tasarım Spektrumlarına Göre Tasarlanan 2 Katlı Binaların İlgili Spektrum Yüklemeleri Altındaki Etkin En Üst Kat Deplasmanları (a, c, e) ve Etkin Göreli Kat Ötelemesi Oranları $(b, d, f)$. 

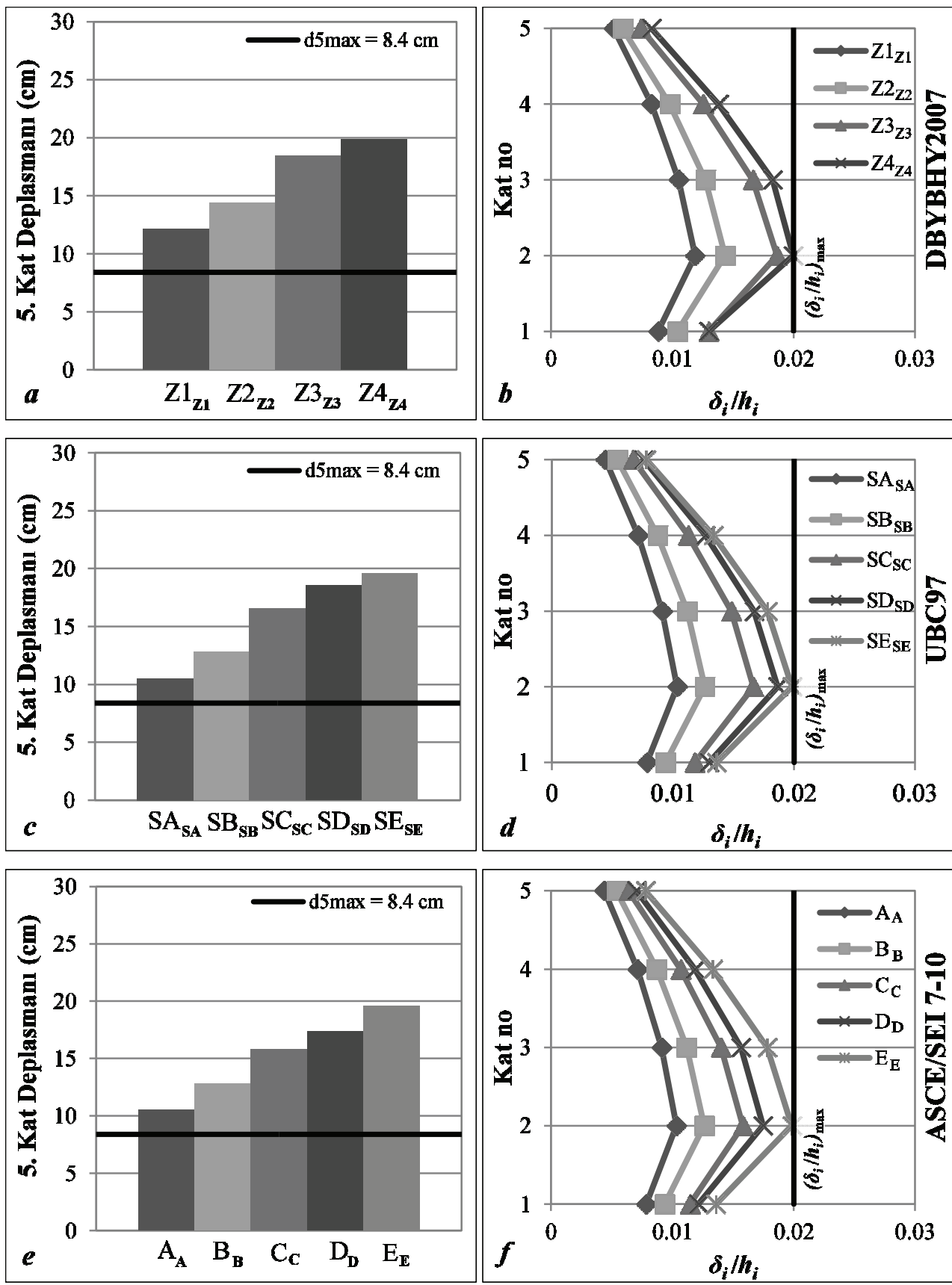

Şekil 14 - Farklı Tasarım Spektrumlarına Göre Tasarlanan 5 Katlı Binaların İlgili Spektrum Yüklemeleri Altındaki Etkin En Üst Kat Deplasmanları (a, c, e) ve Etkin Göreli Kat Ötelemesi Oranları $(b, d, f)$. 

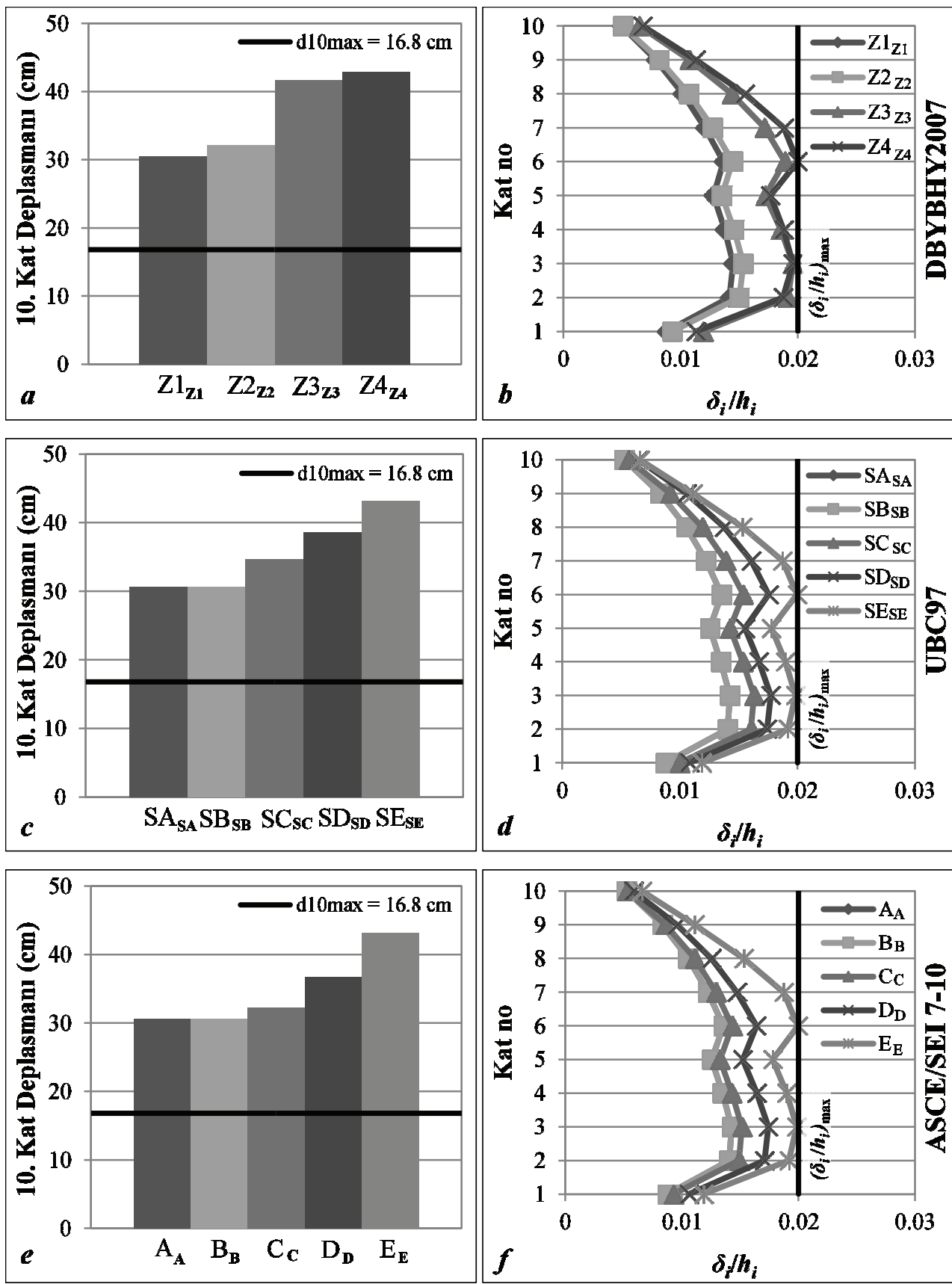

Şekil 15 - Farklı Tasarım Spektrumlarına Göre Tasarlanan 10 Katlı Binaların İlgili Spektrum Yüklemeleri Altındaki Etkin En Üst Kat Deplasmanları (a, c, e) ve Etkin Göreli Kat Ötelemesi Oranları $(b, d, f)$. 

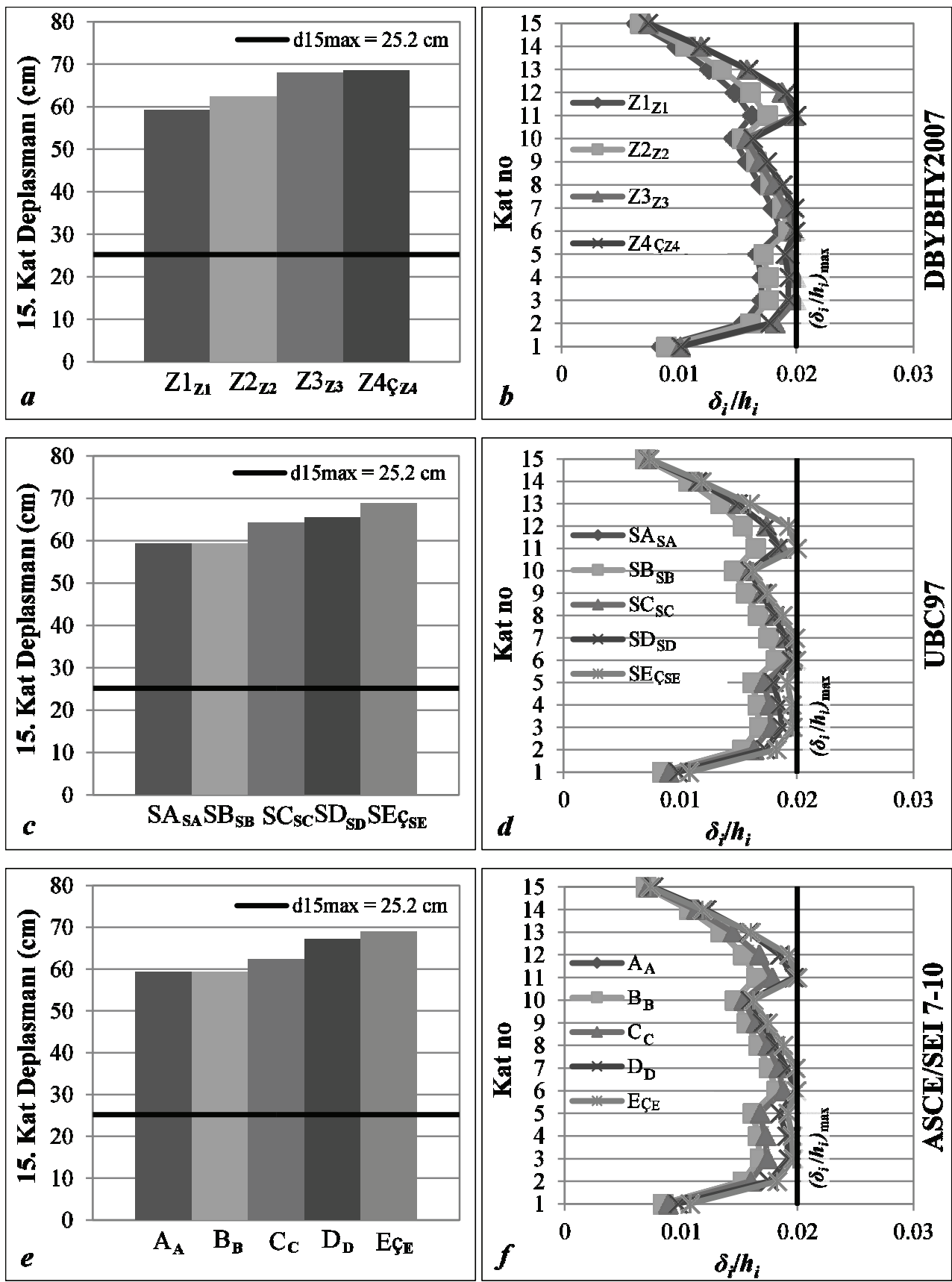

Şekil 16 - Farklı Tasarım Spektrumlarına Göre Tasarlanan 15 Katlı Binaların İlgili Spektrum Yüklemeleri Altındaki Etkin En Üst Kat Deplasmanları (a, c, e) ve Etkin Göreli Kat Ötelemesi Oranları $(b, d, f)$. 

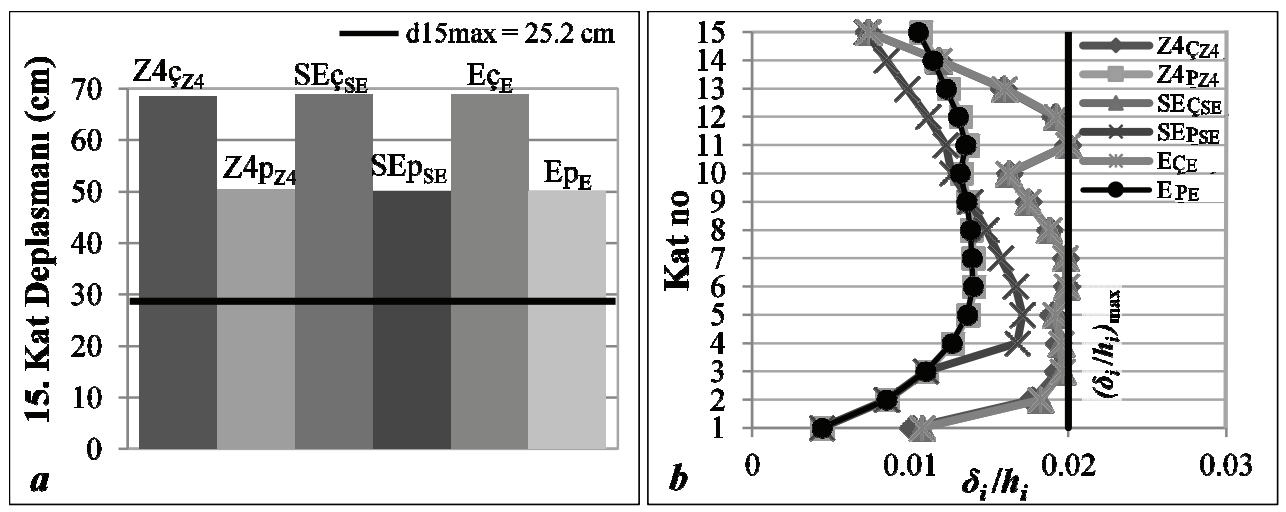

Şekil 17 - En Kötü Zeminler Iç̧in Farklı Tasarım Spektrumlarına Göre Tasarlanan 15 Katlı Binaların İlgili Spektrum Yüklemeleri Altındaki Etkin En Üst Kat Deplasmanları ve Etkin Göreli Kat Ötelemesi Oranlarının Çerçeveli ve Çerçeveli-Perdeli Sistemler İçin Klyaslamasi.

\subsubsection{Z2 Tasarımlarının Z4, SE ve E Spektrumlarına Maruz Bırakılması}

Zemin büyütme katsayılarının tasarımda dikkate alınmasının sismik performans potansiyeli açısından önemini ortaya koyabilmek amacıyla, 2, 5, 10 ve 15 katlı binaların Z2 tasarımları $\mathrm{Z} 4$, SE ve E spektrumlarına maruz birakılmış olup $\left(\mathrm{Z} 2_{\mathrm{Z} 4}, \mathrm{Z} 2_{\mathrm{SE}}, \mathrm{Z} 2_{\mathrm{E}}\right)$ bu durumlara ait etkin en üst kat deplasmanları ve etkin göreli kat ötelemesi oranları Şekil 18'de sunulmuştur. Görüldügü üzere, 2 katlı binalar dışındaki binalar için etkin göreli kat ötelemesi oranları, 0.02 sınırını aşmıştır. Z4 spektrumuna maruz bırakılan durumlarda SE ve E spektrumlarına maruz bırakılan durumlara göre bir miktar daha büyük değerlere ulaşmıştır. Ayrıca, Sindel ve diğ, 1995 [28]'in önerdiği $d N_{\max }$ etkin en üst kat deplasman sınırları da tüm binalar tarafından aşılmış olup, bina toplam kat sayısı arttıkça sınırı aşma miktarı da artmış ve 15 katlı binalarda ilgili sınırın neredeyse 5 katına ulaşmıştır.

\subsubsection{Zaman Tanım Alanı Analizlerine Göre Sismik Performans Potansiyellerinin Karşılaştırması}

Z1, Z2, Z3 ve Z4 tasarım spektrumlarına göre tasarımı yapılan 15 katlı binalar, malzeme, eleman boyutları ve sismik yüke esas zati ve hareketli yükler aynen kullanılarak, zaman tanım alanı analizlerinin yapılabilmesi için bir sonlu elemanlar programında [29] ayrıca modellenmiştir. Sismik yüke esas toplam kat kütleleri binanın ağırlık merkezinde tanımlanmış ve her katta rijit diyafram kabulü yapılmıştır. Detayları Bölüm 3 'te verilen ve SD türü zeminlerde kayıt edilen kuvvetli yer hareketleri (Bkz. Tablo 4) altındaki zaman tanım alanı analizleri neticesinde elde edilen etkin göreli kat ötelemesi oranları ve etkin en üst kat deplasmanları, Z1, Z2, Z3 ve Z4 spektrumlarına göre tasarlanmış olan 15 katlı binalar için karşılaştırmalı olarak sırasıyla Şekil 19 (a-d) ve Şekil 19 (e-h)'de sunulmuştur. 


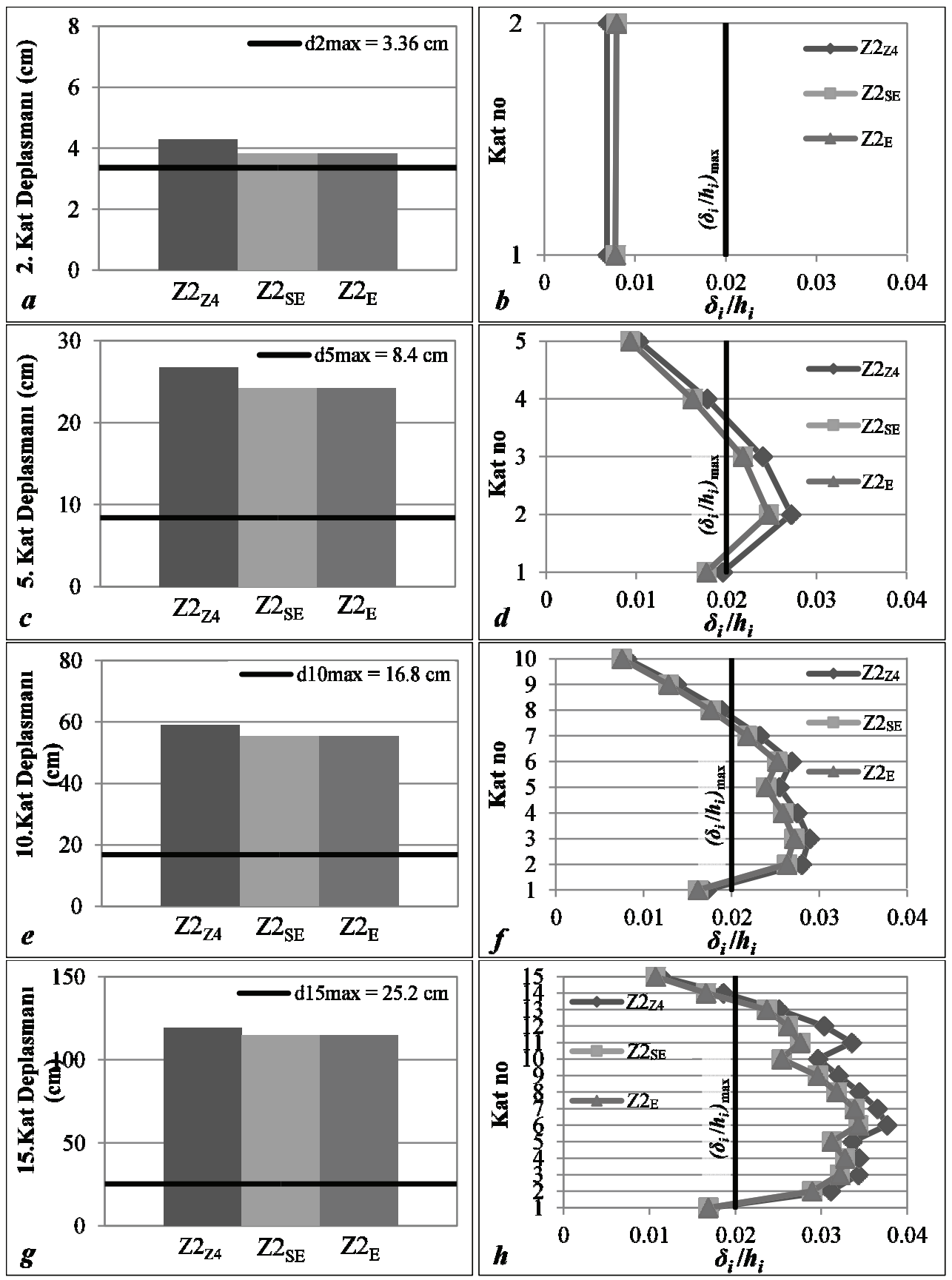

Şekil 18 - Z2 Tasarım Spektrumuna Göre Tasarlanan Binaların Z4, Se ve E Spektrumları Altında Etkin En Üst Kat Deplasmanlart (a, c, e, g) ve Etkin Göreli Kat Ötelemesi Oranları $(b, d, f, h)$. 


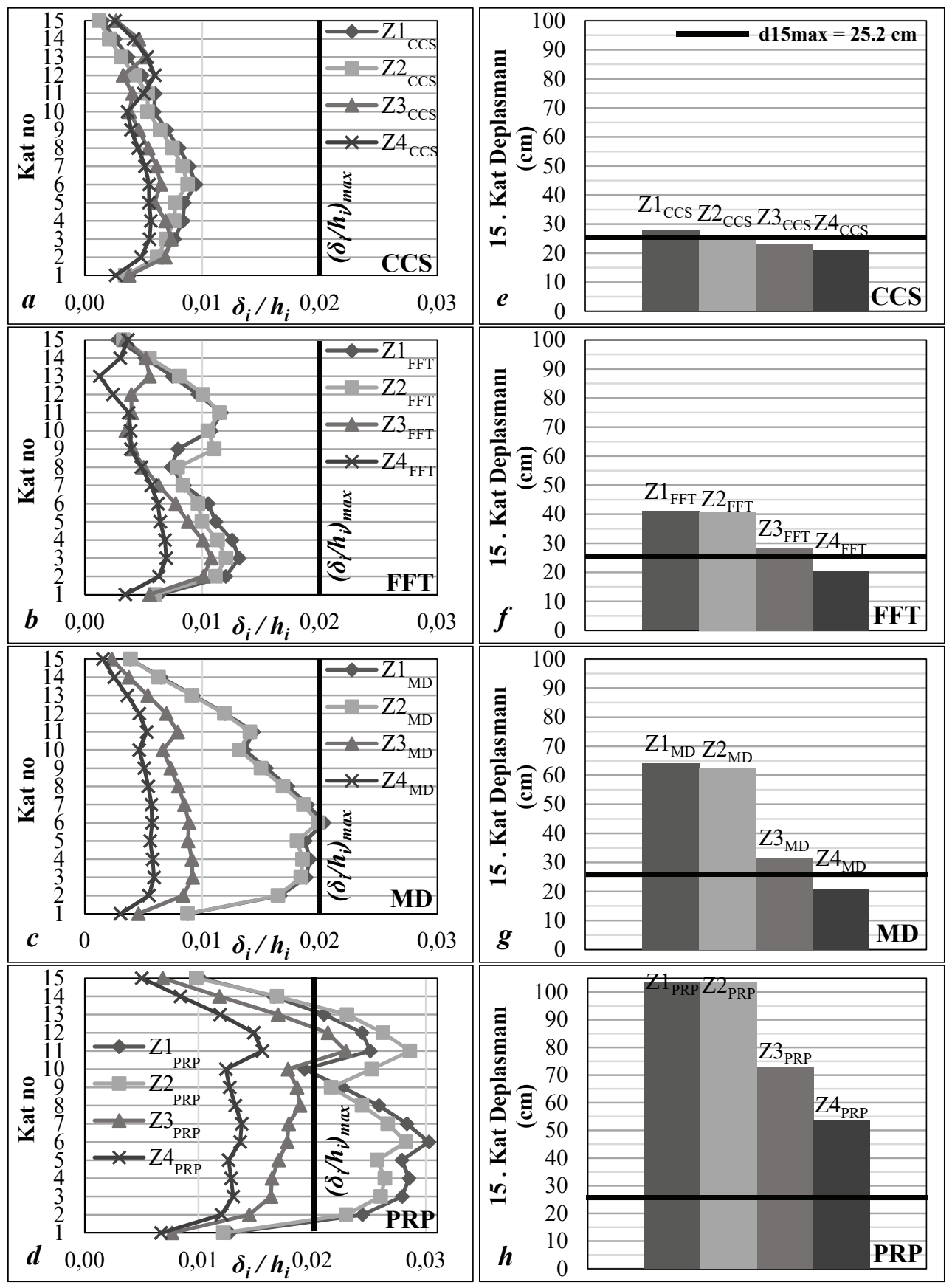

Şekil 19 - 15 Katl Binalarn Etkin Etkin Göreli Kat Ötelemesi Oranlart ve Etkin En Üst Kat Deplasmanlart: (a, e) Cantua Creek School (CCS); (b, f) Fortuna Fire Station (FFT); (c, g) Michocan De Ocampo (MD); (d, h) Pages Road Pumping Station (PRP) Kaydl Altinda. 
Şekil 19a ve b'den görüldüğü üzere, Cantua Creek School (CCS) ve Fortuna Fire Station (FFT) kayıtlarına maruz bırakılan Z1, Z2, Z3 ve Z4 tasarımları $\left(Z 1_{\mathrm{CCS}}, \mathrm{Z}_{\mathrm{CCS}}, \mathrm{Z}_{\mathrm{CCS}}, \mathrm{Z}_{\mathrm{CCS}}\right.$, $Z_{\text {FFT, }} Z 2_{\mathrm{FFT}}, 3_{\mathrm{FFT}}$ ve $\mathrm{Z}_{\mathrm{FFT}}$ ) için elde edilen etkin göreli kat ötelemesi oranlarının tamamı, DBYBHY2007 yönetmeliğinde tanımlanmış olan $\left(\delta_{i} / h_{i}\right)_{\max }=0.02$ sınırının altında kalmaktadır. Diğer taraftan, Şekil 19c'de görüldüğü üzere; Michocan De Ocampo (MD) kaydına maruz bırakılan $Z 3$ ve $Z 4$ tasarımları $\left(Z 3_{M D}\right.$ ve $\left.Z 4_{M D}\right)$ için elde edilen etkin göreli kat ötelemesi oranları 0.02 sınırının çok altında kalırken; Z2 tasarımı (Z2 $2_{\mathrm{MD}}$ ) için sınırda değerler almakta, Z1 tasarımı $\left(Z_{\mathrm{MD}}\right)$ için ise bu sınır az da olsa aşılmaktadır. Söz konusu Z1, Z2, Z3 ve Z4 tasarımlarının yukarıda bahsi geçen üç deprem kaydına göre daha agresif bir deprem kaydı olan Pages Road Pumping Station (PRP) yer hareketi kaydına maruz kalması halinde ise (Şekil 19d), bu tasarımlar arasından sadece Z4 tasarımı (Z4 $4_{\mathrm{PRP}}$ ) için elde edilen etkin göreli kat ötelemesi oranları 0.02 sınırını aşmaz iken; söz konusu sınır, özelikle Z1 ve Z2 tasarımları (Z1 $1_{\text {PRP ve Z2 }}$ PRP) için önemli ölçüde aşılmaktadır. Durumu etkin en üst kat deplasmanları açısından ortaya koyan grafikler ise, Şekil 19 (e-h)'de sunulmuştur. Z1 ve Z2 tasarımları için elde edilen etkin en üst kat deplasmanları CCS kaydı altında Şekil 19e'den görüldüğü üzere Sindel ve diğ., 1995 [28] tarafından önerilen $d 15_{\max }=25.2 \mathrm{~cm}$ sınırına yakın değerler almakta iken, FFT, MD ve PRP kayıtları altında ise sınır ciddi şekilde aşılmaktadır (sırasıyla yaklaşık $41 \mathrm{~cm}, 64 \mathrm{~cm}$ ve $103 \mathrm{~cm}$ ). Z3 tasarımı için etkin en üst kat deplasmanları açısından belirlenen sismik performans potansiyeli Z1 ve Z2 tasarımlarına göre daha üstün olmakla birlikte $d 15_{\max }=25.2 \mathrm{~cm}$ sınırı FFT, MD ve PRP kayıtları altında (özellikle PRP için) yine de aşılmaktadır (sırasıyla yaklaşık $28 \mathrm{~cm}, 32 \mathrm{~cm}$ ve $73 \mathrm{~cm}$ ). Z4 tasarımının etkin en üst kat deplasmanları açısından en yüksek sismik potansiyele sahip olduğu ve PRP kaydı hariç tüm kayıtlar altında $d 15_{\max }=25.2 \mathrm{~cm}$ sınırının altında değerler aldığ görülmüştür Görüldüğü üzere, yönetmeliklerde önerilen zemin büyütme etkileri dikkate alınarak yapılan tasarımlar, tasarımda öngörülene benzer kötü bir zeminde (SD) alınan gerçek bir deprem kaydına maruz kalması halinde, diğer tasarımlara göre etkin göreli kat ötelemesi oranları ve etkin en üst kat deplasmanları açısından genel olarak başarılı bir sismik performans potansiyeli ortaya koymaktadır.

\section{SONUÇLAR}

$\mathrm{Bu}$ çalışmada, zemin büyütme katsayılarının çerçeve türü betonarme binaların taşıyıcı sistemlerinin sismik performans potansiyeli ve maliyetine olan etkilerinin araştırılması amacıyla az ve orta katlı binaları temsilen 2 ve 5 katlı ve çok katlı binaları temsilen 10 ve 15 katlı prototip binalar, farklı spektrumlar kullanılarak (DBYBHY2007'de Z1, Z2, Z3, Z4, UBC97'de SA, SB, SC, SD, SE ve ASCE/SEI 7-10'da A, B, C, D, E) DBYBHY2007'ye göre tasarlanmıştır. 15 katlı bina, perdeli-çerçeveli olarak da en kötü zeminler (Z4, SE ve E) için ayrıca tasarlanmıştır. Bu binalar tüm spektrumlara ve ayrıca, 15 katlı binalar seçilen örnek tarihi deprem kayıtlarına maruz bırakılarak sismik performans potansiyeli karşılaştırmaları yapılmıştır. Yapısal taşıyıcı sistem tasarımlarında öncelikli unsur "güvenlik" olmakla birlikte, "maliyet" unsurunun mühendislik uygulaması açısından bunun akabinde göz önünde bulundurulması gereken önemli bir husustur. Bu sebeple, bu çalışmada farklı zemin özelliklerine bağlı olarak farklı yönetmeliklerin getirdiği koşullar maliyet açısından da karşılaştırılmış ve bu koşullara göre tasarlanan binaların sismik performans potansiyelleri (güvenlik seviyeleri) ile birlikte değerlendirilmiştir. Elde edilen sonuçlar şu şekilde özetlenebilir: 
1. Z2 spektrumuna göre tasarlanmış binalar ile (i) Z1, SA veya A türü zeminlere ait spektrumlara göre tasarlanmış binalar karşılaştırıldığında, maliyette azalma 2 ve 5 katlı binalarda anlamlı mertebelerde (\%8 civarı) olup 10 ve 15 katl önemsenmeyecek kadar azdır; (ii) Z4 (SC, SD, SE veya C, D, E) türü zeminlere ait spektrumlara göre tasarlanmış çerçeveli binalar karşılaştırıldığında, maliyette kayda değer artışlar 10 ve 15 katlı binalarda görülmektedir. Maliyet artışı Z4 için 15 katlı binalarda yaklaşık \%33'e, E ve SE için ise yaklaşık \%27'ye ulaşmıştır. Yani, Z4 spektrumu daha büyük deprem kuvvetlerine göre tasarım gerektirmekte ve daha maliyetli olmaktadır; (iii) Z4, SE ve E türü zeminlere ait spektrumlara göre tasarlanmış 15 katlı perdeli-çerçeveli binalar karşılaştırıldığında, maliyet farkı \% 44 'e ulaşmaktadır. Perdeliçerçeveli sistemler daha maliyetli olmakla birlikte özellikle etkin en üst kat deplasmanlarının sınırlandırılmasında önemli rol oynamaktadır.

2. Prototip binalar, tasarlandıkları spektrum yüklemelerine maruz bırakıldıklarında, Sindel ve diğ, 1995 [28] tarafından ortaya konan etkin en üst kat deplasmanı sınılarının aşıldığı belirlenmiş̧tir. Dolayısıyla, yönetmeliklere, etkin en üst kat deplasmanına bağlı bir sınırın da getirilmesinin uygun olacağı değerlendirilmiştir.

3. Yönetmeliklerde önerilen zemin büyütme katsayıları dikkate alınarak yapılan tasarımların, tasarımda öngörülene benzer kötü zeminlere ait deprem kayıtları altında başarılı bir sismik performans potansiyeli sergilediği, bu katsayılar dikkate alınmadan yapılacak tasarımların ise başarısız olabileceği belirlenmiştir.

4. DBYBHY2007, zemin büyütme etkisini uzun periyotlu yapılar için (sabit hız bölgesinde) ciddi bir şekilde dikkate almakta ve diğer Amerikan yönetmelikleri ile TBDY 2019'a göre daha yüksek spektral ivme değerleri öngörmektedir. Ancak, DBYBHY2007 sabit ivme bölgesinde zemin büyütme etkisini UBC97 ve ASCE/SEI 7-10 veya TBDY 2019 yönetmeliklerindeki gibi dikkate almamakta ve spektral ivme değerleri bu yönetmeliklerdekilerin altında kalabilmektedir. Dolayısıyla TBDY2019, DBYBHY2007'ye göre spektral ivmelerde sabit hız bölgesinde azalma, sabit ivme bölgesinde ise artış getirmektedir.

$\mathrm{Bu}$ çalışmadaki binaların, DBYBHY2007'deki 1. Derece Deprem Bölgesinde olduğu varsayılmış olup; sonuçlar bu varsayım için geçerlidir. Diğer taraftan, kısa periyot bölgesi için tanımlanan yerel zemin etki katsayıları özellikle 3. ve 4. Derece Deprem Bölgelerinde en iyi zeminden en kötüye doğru arttı̆̆ından, bu deprem bölgelerinde farklı zemin sınıfları üzerinde inşa edilen az katlı yapıların sismik performans potansiyelleri arasındaki farklılığın da artması beklenir. Bu nedenle, söz konusu bölgeler farklı bir çalışma ile ayrıca ele alınabilir.

\section{Semboller}

$\begin{array}{ll}A_{0} & : \text { Etkin yer ivmesi katsayısı } \\ B_{k} & : \text { Z2’ye göre zemin büyütme katsayısı } \\ C_{a}, C_{v} & : \text { Sismik katsayılar } \\ d N & : \text { Etkin en üst kat deplasmanı }\end{array}$ 
$F_{a}, F_{v} \quad:$ ASCE/SEI 7-10'da tanımlanan zemin büyütme katsayıları

$h_{i} \quad$ : Binanın i. kat yüksekliği

$h_{1} \quad$ : En üst zemin tabakası kalınlığı

I : Bina önem katsayısı

$M \quad$ : Deprem hareketinin maksimum moment magnitüdü

$N_{a}, N_{v} \quad$ : Yakın kaynak katsayıları

$N_{S P T} \quad$ : Zeminin standart penetrasyon direnci

$P I \quad$ : Plastisite indeksi

$R \quad$ : Taşıyıcı sistem davranış katsayısı

$S(T) \quad$ : Tasarım ivme spektrum katsayısı

SR : Kayma hızı

$S_{u} \quad$ : Drenajsiz kayma mukavemeti

$S_{a} \quad$ : Spektral ivme

$S_{s}, S_{1} \quad$ : Harita spektral ivme değerleri

$S_{M S}, S_{M 1}$ : Maksimum deprem seviyesi için spektral ivme parametreleri

$S_{D \mathrm{~S}}, \mathrm{~S}_{D 1}:$ Tasarım spektral ivme parametreleri

$T \quad$ : Yapı doğal periyodu

$T_{A}, T_{B} \quad$ : DBYBHY2007'de tanımlanan spektrum karakteristik periyotları

$T_{0}, T_{S} \quad$ : ASCE/SEI 7-10' da tanımlanan spektrum karakteristik periyotları

$V_{s} \quad:$ Zeminin kayma dalgası hızı

Z : UBC97'de tanımlanan sismik bölge faktörü

$\Delta_{x} \quad$ : İki kat arasındaki deplasman farkı

$\delta_{i} \quad$ : Binanın i. katındaki etkin göreli kat ötelemesi

\section{Kaynaklar}

[1] DBYBHY, Deprem Bölgelerinde Yapılacak Binalar Hakkında Yönetmelik, T.C. Bayındırlık ve İskan Bakanlığı, Ankara, 2007.

[2] UBC, Uniform Building Code, International Conference of Building Officials, California.

[3] ASCE/SEI 7-10, Minimum Design Loads for Buildings and Other Structures, American Society of Civil Engineers, 2010.

[4] Tehranizadeh, M., Hamedi, F., Influence of earthquake source parameters and damping on elastic response spectra, Fourth International Conference On Recent Advances In Geotechnical Earthquake Engineering And Soil Dynamics, 2001. 
[5] Finn, L.W.D., Wightman, A., Ground motion amplification factors for the proposed 2005 edition of the National Building Code of Canada, Canadian Journal of Civil Engineering, 30, 272-278, 2003.

[6] Pitilakis, K., Riga, E., Anastasiadis, A., Design spectra and amplification factors for Eurocode 8, Bulletin of Earthquake Engineering, 10 (5), 1377-1400, 2012.

[7] Tezcan, S., Kaya, E., Bal, E.I., Özdemir, Z., Seismic amplification at Avcılar, Istanbul, Engineering Structures, 24, 661-667, 2002.

[8] Trifunac, M., How to model amplification of strong earthquake motions by local soil and geologic site conditions, Earthquake Engineering and Structural Dynamics, 19, 833-846, 1990.

[9] Bouckovalas, G.D., Kouretzis, G.P., Stiff soil amplification effects in the 7 September 1999 Athens (Greece) earthquake, Soil Dynamics and Earthquake Engineering, 21, 671- 687, 2001.

[10] FEMA 368-369, NEHRP- Recommended provisions for seismic regulations for new buildings, Buildings Seismic Safety Council, Washington D.C., USA, 1997.

[11] Eurocode 8, Design of structures for earthquake resistance Part 1: general rules, seismic actions and rules for buildings, European Norm, European Committee for Standardisation, Brussels, 2004.

[12] Şafak, E., Local site effects and dynamic soil behavior, Soil Dynamics and Earthquake Engineering, 21, 453- 458, 2001.

[13] Zaslavsky, Y., Shapira, A., Gorstein, M., Perelman, N., Ataev, G., Aksinenko, T., Questioning the applicability of soil amplification factors as defined by NEHRP (USA) in the Israel building standards, Natural Science, 631-639, 2012.

[14] Şişman, F.N., Zeminlerin dinamik özelliklerinin ve zemin büyütme faktörlerinin alternatif yöntemlerle belirlenmesi, Yüksek lisans tezi, Deprem Mühendisliği, 2013.

[15] Bessason, B., Kaynia, A.M., Site amplification in lava rock on soft sediments, Soil Dynamics and Earthquake Engineering, 22, 525-540, 2002.

[16] Zembaty, Z., Rutenberg, A., Spatial response spectra and site amplification effects, Engineering Structures, 24, 1485-1496, 2002.

[17] Stewart, J., Choi, Y., Liu, A., Amplification factors for spectral acceleration in active regions, PEER Annual Meeting Research Digest, 14, 2002.

[18] Choi, Y., Stewart, P.J., Nonlinear site amplification as function of $30 \mathrm{~m}$ shear wave velocity, Earthquake Spectra, 21, 1-30, 2005.

[19] Tsang, H., Lam, T.K.N., Wilson, L.J., A design spectrum model featuring resonant-like soil-amplification, Australian Earthquake Engineering Society Conference, Kasim 2013, Hobart Tasmania, 2013.

[20] Khanbabazadeh, H., Anakaya eğiminin zemin büyütmesine etkisi, İstanbul Teknik Üniversitesi, Fen Bilimleri Enstitüsü, Doktora tezi, 2014. 
[21] Finn, L.W.D , Ruz, F., Amplification effects of thin soft surface layers: A study for NBCC 2015, Geotechnical, Geological and Earthquake Engineering, 37, 32-42, 2015.

[22] Kuruoglu, M., Eskisar, T., Effect of local soil conditions on dynamic ground response in the southern coast of Izmir Bay, Turkey, Russian Geology and Geophysics, 56, 1201-1212, 2015.

[23] Azimi, P., Zemin büyütme katsayılarının betonarme taşıyıcı sistemlerin deprem performansına ve maliyetine etkileri, İstanbul Üniversitesi, Fen Bilimleri Enstitüsü, İnşaat Mühendisliği Anabilim Dalı, 2016.

[24] Benmokhtar, N., Yakın fay katsayılarının betonarme taşıyıcı sistemlerin deprem performansına ve maliyetine etkileri, İstanbul Üniversitesi, Fen Bilimleri Enstitüsü, İnşaat Mühendisliği Anabilim Dalı, 2014.

[25] TS500 Türk Standardı: Betonarme Yapıların Tasarım ve Yapım Kuralları, TSE, Şubat 2000 .

[26] STA4-CAD, Structural Analysis for Computer Aided Design, Bilgisayar Destekli Tasarım için Yapısal Analiz, Ankara, 2015.

[27] PEER Ground Motion Database, Pacific Earthquake Engineering Research Center, University of California, Berkeley, CA 94720-1792, peer center@berkeley.edu, 2013.

[28] Sindel, Z., Akbaş, R., Tezcan, S., Drift control and damage in tall buildings, Engineering Structures, 18, 957-966, 1995.

[29] SAP2000, Integrated Software for Structural Analysis and Design: Computers and Struct. Inc. Berkeley, California, 2015. 